Prepared in cooperation with the Bureau of Land Management and the Idaho Department of Environmental Quality

\title{
Spatial and Temporal Trends in Selenium in the Upper Blackfoot River Watershed, Southeastern Idaho, 2001-16
}

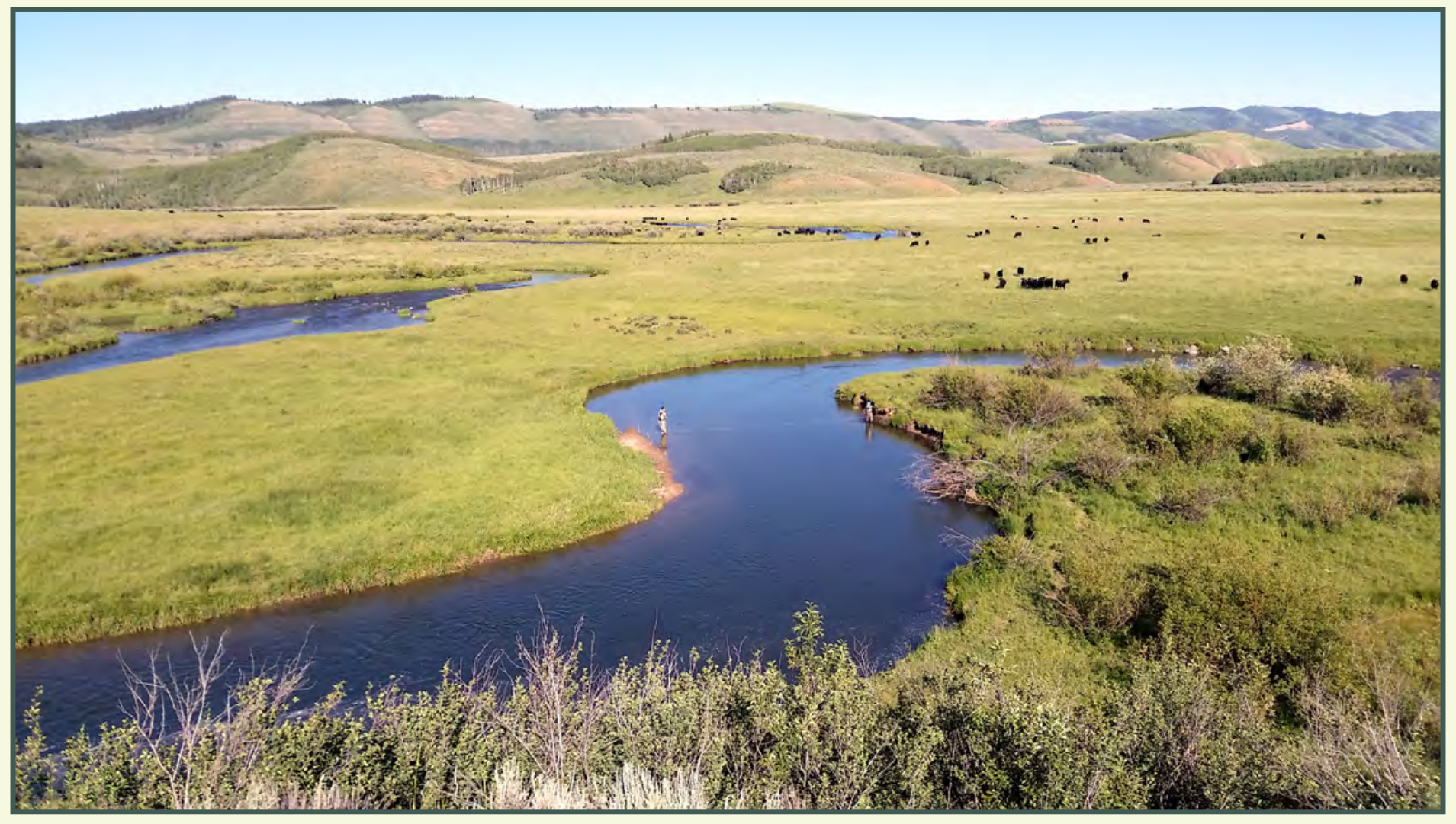

Scientific Investigations Report 2018-5081 
Cover: Upper Blackfoot River, looking east across mouth of Dry Valley and toward the Maybe Canyon Mines, southeastern Idaho. Photograph by Chris Mebane, U.S. Geological Survey, June 21, 2016, during sampling for the seepage study. 


\section{Spatial and Temporal Trends in Selenium in the Upper Blackfoot River Watershed, Southeastern Idaho, 2001-16}

By Lauren M. Zinsser, Christopher A. Mebane, Greg C. Mladenka, Lynn R. Van Every, and Marshall L. Williams

Prepared in cooperation with the Bureau of Land Management and the Idaho Department of Environmental Quality

Scientific Investigations Report 2018-5081 


\title{
U.S. Department of the Interior \\ RYAN K. ZINKE, Secretary
}

\author{
U.S. Geological Survey \\ James F. Reilly II, Director
}

U.S. Geological Survey, Reston, Virginia: 2018

For more information on the USGS - the Federal source for science about the Earth, its natural and living resources, natural hazards, and the environment—visit https://www.usgs.gov or call 1-888-ASK-USGS.

For an overview of USGS information products, including maps, imagery, and publications, visit https://store.usgs.gov.

Any use of trade, firm, or product names is for descriptive purposes only and does not imply endorsement by the U.S. Government.

Although this information product, for the most part, is in the public domain, it also may contain copyrighted materials as noted in the text. Permission to reproduce copyrighted items must be secured from the copyright owner.

Suggested citation:

Zinsser, L.M., Mebane, C.A., Mladenka, G.C., Van Every, L.R., and Williams, M.L., 2018, Spatial and temporal trends in selenium in the upper Blackfoot River watershed, southeastern Idaho, 2001-16: U.S. Geological Survey Scientific Investigations Report 2018-5081, 37 p., https://doi.org/10.3133/sir20185081.

ISSN 2328-0328 (online) 


\section{Contents}

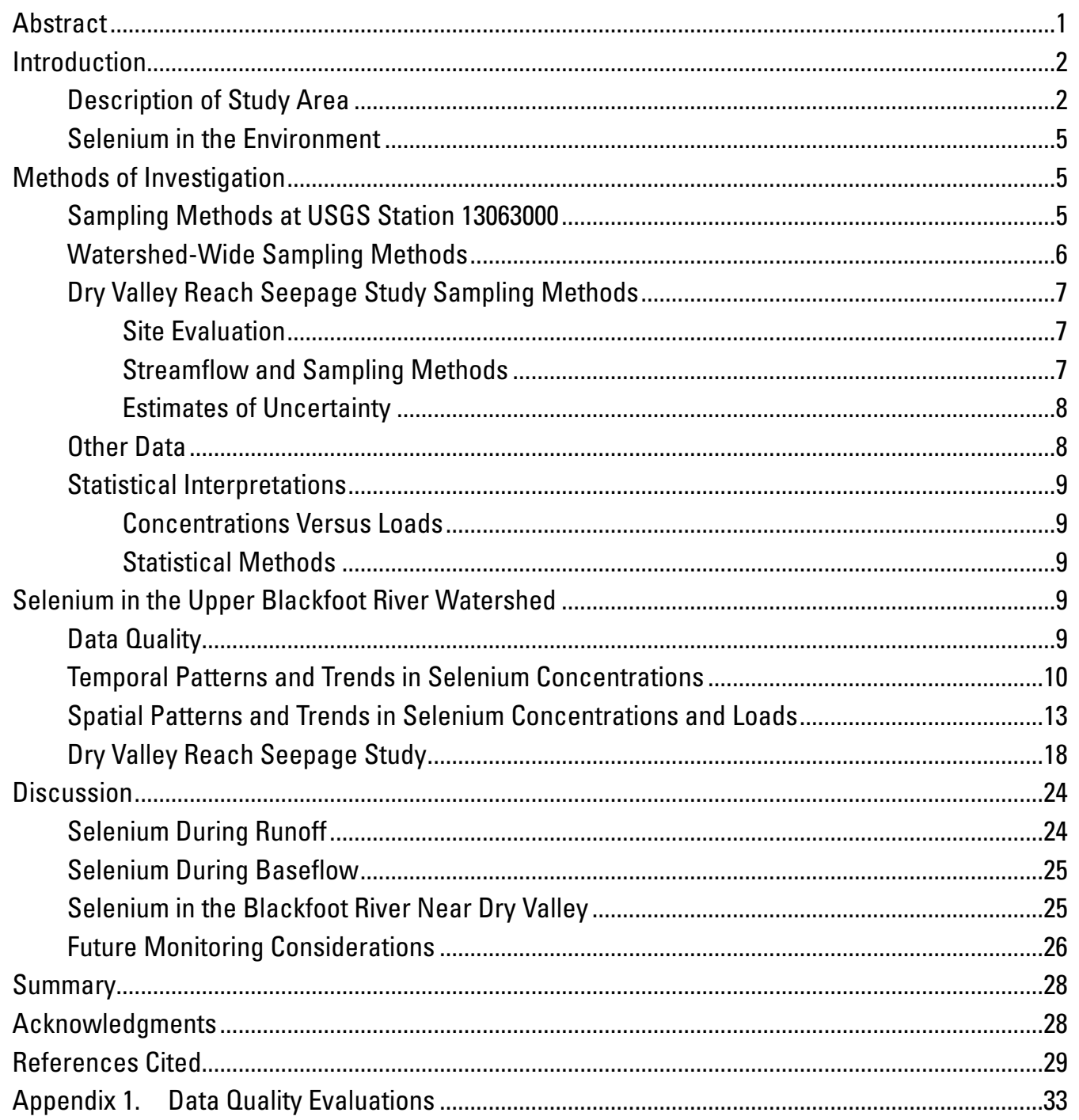




\section{Figures}

1. Map showing phosphate mines and monitoring stations in the upper Blackfoot River watershed study area, southeastern, Idaho, 2001-16

2. Schematic diagram showing hierarchy of tributaries and phosphate mines in relation to the Idaho Department of Environmental Quality (IDEO) sampling stations on the mainstem upper Blackfoot River (open circles) and tributaries, southeastern Idaho

3. Graph showing selenium concentration (total and dissolved) and streamflow in the Blackfoot River above reservoir near Henry, Idaho (13063000), 2001-16 .11

4. Graphs showing annual patterns of selenium concentrations (total and dissolved) and streamflow in the Blackfoot River above reservoir near Henry, Idaho (13063000), calendar year 2009-16.

5. Boxplots of selenium concentrations (total and dissolved) during (April and May (runoff streamflow) and August, September, and October (baseflow) in the Blackfoot River above reservoir near Henry, Idaho (13063000).

6. Time series graphs showing selenium concentrations (total and dissolved) during April and May (runoff streamflow) and August, September, and October (baseflow) in the Blackfoot River above reservoir near Henry, Idaho (13063000).

7. Graph showing total water year precipitation in the upper Blackfoot River watershed, southeastern, Idaho, water years 2001-16

8. Graphs and boxplot showing selenium concentrations in Blackfoot River mainstem and tributaries from Idaho Department of Environmental Quality annual spring runoff sampling (2001-16)...

9. Graphs showing cumulative streamflow and selenium load accumulation in the Blackfoot River and tributaries, southeastern Idaho. Measured by the Idaho Department of Environmental Quality during spring runoff in 2007, 2009, and 2011-16

10. Graphs showing seepage study streamflow and selenium load accumulation in the Blackfoot River and tributaries, upper Blackfoot River watershed, southeastern, Idaho

\section{Tables}

1. Annual summaries of selenium concentrations (total and dissolved data included) collected by autosampler at U.S. Geological Survey streamgage, Blackfoot River above Reservoir near Henry, Idaho (13063000), 2013-16

2. Spearman correlations between selenium concentration and streamflow at sites in the upper Blackfoot River watershed, southeastern, Idaho, 2001-16.

3. Selenium concentrations and loads from synoptic surveys of East Mill Creek, Spring Creek, and the Blackfoot River, 2013-16

4. Streamflow and selenium concentrations (dissolved) and loads from the Dry Valley reach seepage study, upper Blackfoot River watershed, southeastern, Idaho

5. Site-specific aquatic life criterion values for the upper Blackfoot River watershed, southeastern Idaho

6. Summary of selenium concentrations in fish tissue reported from collections that overlapped in time with water sampling by U.S. Geological Survey or Idaho Department of Environmental Quality, mainstem upper Blackfoot River, southeastern Idaho 


\section{Conversion Factors}

U.S. customary units to International System of Units

\begin{tabular}{lcl}
\hline \multicolumn{1}{c}{ Multiply } & By & To obtain \\
\hline mile $(\mathrm{mi})$ & Length & \\
\hline & 1.609 & kilometer $(\mathrm{km})$ \\
\hline square mile $\left(\mathrm{mi}^{2}\right)$ & Area & square kilometer $\left(\mathrm{km}^{2}\right)$ \\
\hline & 2.590 & \\
\hline cubic foot $\left(\mathrm{ft}^{3}\right)$ & Volume & cubic meter $\left(\mathrm{m}^{3}\right)$ \\
\hline & 0.02832 & \\
\hline foot per second $(\mathrm{ft} / \mathrm{s})$ & Flow rate & meter per second $\left(\mathrm{m}^{3} / \mathrm{s}\right)$ \\
cubic foot per second $\left(\mathrm{ft}^{3} / \mathrm{s}\right)$ & 0.3048 & cubic meter per second $\left(\mathrm{m}^{3} / \mathrm{s}\right)$ \\
gallon per day $(\mathrm{gal} / \mathrm{d})$ & 0.02832 & cubic meter per day $\left(\mathrm{m}^{3} / \mathrm{d}\right)$ \\
\hline
\end{tabular}

International System of Units to U.S. customary units

\begin{tabular}{|c|c|c|}
\hline Multiply & By & To obtain \\
\hline & Volume & \\
\hline liter (L) & 33.81402 & ounce, fluid (fl. oz) \\
\hline liter $(\mathrm{L})$ & 1.057 & quart (qt) \\
\hline \multirow[t]{2}{*}{ liter (L) } & 0.2642 & gallon (gal) \\
\hline & Mass & \\
\hline kilogram (kg) & 2.205 & pound avoirdupois (lb) \\
\hline
\end{tabular}

\section{Datums}

Vertical coordinate information is referenced to the North American Vertical Datum of 1929 (NAVD 29).

Horizontal coordinate information is referenced to the North American Datum of 1983 (NAD 83).

Elevation, as used in this report, refers to distance above the vertical datum. 


\section{Supplemental Information}

Concentrations of chemical constituents in water are given either in milligrams per liter (mg/L) or micrograms per liter $(\mu \mathrm{g} / \mathrm{L})$. Concentrations of chemical constituents in rock are given in milligrams per kilogram $(\mathrm{mg} / \mathrm{kg})$ and in fish tissue are given in milligrams per kilogram dry weight (mg/kg dry weight).

\section{Abbreviations}

$\begin{array}{ll}\text { BAF } & \text { bioaccumulation factor } \\ \text { dw } & \text { dry weight } \\ \text { EWI } & \text { equal width increment } \\ \text { GPS } & \text { Global Positioning System } \\ \text { IDEO } & \text { Idaho Department of Environmental Quality } \\ \text { MPV } & \text { most probable values } \\ \text { NWQL } & \text { National Water Quality Laboratory } \\ \text { RSD } & \text { relative sample deviation } \\ \text { Se } & \text { selenium } \\ \text { USGS } & \text { U.S. Geological Survey }\end{array}$




\title{
Spatial and Temporal Trends in Selenium in the Upper Blackfoot River Watershed, Southeastern Idaho, 2001-16
}

\author{
By Lauren M. Zinsser, ${ }^{1}$ Christopher A. Mebane, ${ }^{1}$ Greg C. Mladenka, ${ }^{2}$ Lynn R. Van Every, ${ }^{2}$ and \\ Marshall L. Williams ${ }^{1}$
}

\section{Abstract}

Phosphate mining in southeastern Idaho has been an important economic driver for the region and State for over 100 years, but weathering of mining waste rock has also released selenium into the Blackfoot River. This report analyzes and presents data from three separate but complementary studies monitoring selenium in streams in the region. The U.S. Geological Survey (USGS), in cooperation with the Bureau of Land Management, has been collecting streamflow and water-quality samples year-round on the Blackfoot River above reservoir near Henry, Idaho, (USGS streamgage 13063000) since 2001. Over the same period, the Idaho Department of Environmental Quality (IDEQ) has collected streamflow and water-quality samples from the Blackfoot River and tributaries during spring runoff. Data collected from 2001 to 2012 during these two studies were analyzed previously. This report extends the analysis using new data collected through 2016. This report also presents the results of a joint USGS and IDEQ seepage study conducted in June 2016 in the Blackfoot River near Dry Valley. Although limited in scope, this study explored the hypothesis that unaccounted selenium loading (loading in excess of tributary inputs) in this reach could be caused by groundwater inflow.

USGS dissolved selenium concentration data from streamgage 13063000 on the Blackfoot River and IDEQ data from the mainstem and mining-affected tributaries are highest shortly after peak runoff and correlate with streamflow magnitude. Although earlier analyses indicated increasing selenium concentrations from 2001 to 2012, this study shows that runoff and baseflow dissolved selenium concentrations increased and then decreased during 2001-16. High median runoff concentrations from 2005 through 2011 are associated with high snowpack and streamflow. This result suggests that more snowmelt moving through selenium-bearing waste rock leads to increased instream concentrations. The time lag between peak runoff and then peak selenium concentrations suggests that selenium mobilization may occur as snowmelt percolates through waste rock rather than by faster surface runoff. However, variability in local snow accumulation and snowmelt conditions likely affects interannual variability in selenium concentrations in the mainstem Blackfoot River and tributaries.

In contrast to runoff selenium concentrations, median baseflow (August to October) dissolved selenium concentrations were highest from 2009 to 2013. Aquatic plant senescence and release of selenium is an unlikely explanation for this trend because plants are still growing during this time of year. In addition, this trend is observed during and shortly after the observed period of high snowpack. Thus, increased baseflow selenium concentrations suggest that increased selenium loading to alluvial groundwater may occur during periods of high snowmelt and manifest in later years as higher instream concentrations during baseflows when the majority of streamflow is attributable to groundwater gains.

Runoff-period streamflow and selenium loads were calculated for the tributaries and mainstem Blackfoot River. Selenium loads vary from year to year with mainstem loads greater than the total tributary contributions in some years and less than tributary contributions in other years. In general, East Mill Creek usually accounted for the largest proportion of the total Blackfoot River load, and unaccounted loads (loads in excess of tributary inputs) often occurred in the vicinity of Spring Creek and Dry Valley. The latter observation led the USGS and IDEQ to conduct a seepage study to further investigate groundwater and selenium loading to the Blackfoot River near Dry Valley.

\footnotetext{
${ }^{1}$ U.S. Geological Survey.

${ }^{2}$ Idaho Department of Environmental Quality.
} 
The seepage study results show consistent albeit small unaccounted increases in streamflow and dissolved selenium load in the Blackfoot River near Dry Valley. Field observation of a spring to the north of the river and independent groundwater monitoring data from Dry Valley to the south of the river suggest that alluvial groundwater may discharge to the river from both sides. However, the small unaccounted selenium load measured in the June 2016 study relative to loads measured during runoff suggest that groundwater loading in this reach may occur primarily during runoff. An improved understanding of alluvial groundwater extent, gradient, hydraulic conductivity, and quality would aid in interpreting unaccounted gains and losses in selenium loads in the Blackfoot River.

Finally, State of Idaho selenium water-quality criteria have recently shifted to a hierarchical fish tissue and water concentration scheme. This report summarizes existing fish tissue and water-quality data in the mainstem and offers considerations for future selenium monitoring in the Blackfoot River.

\section{Introduction}

Phosphate mining and processing in southeastern Idaho has been an important economic activity since the early 1900s. Mining targets the Permian Phosphoria Formation that hosts rocks rich in phosphorus ore and selenium. In the mid-1990s, selenium contamination was identified as an environmental concern in the area following a series of livestock deaths. Since that time, numerous studies have been conducted to understand the extent, magnitude, and mechanisms of selenium contamination and transport throughout the watershed (for example, Hein, 2004).

Mebane and others (2015) compiled water-quality data collected by the U.S. Geological Survey (USGS) and the Idaho Department of Environmental Quality (IDEQ) from 2001 through 2012 and described spatial and temporal patterns in selenium concentrations and loading in the Blackfoot River and tributaries. This analysis showed that the highest selenium concentrations occur during high spring runoff flows, and that in most years the majority of selenium loading could be attributed to a single tributary, East Mill Creek. However, Mebane and others (2015) also noted that selenium load increased with distance downstream in some years and that the increase in selenium load near Dry Valley could not be explained by measured tributary loads. This finding suggested that groundwater inflow was a potential source of selenium loading, which led to the Dry Valley reach seepage study.
This report presents the results of the Dry Valley reach seepage study and updates Mebane and others (2015) work by extending and analyzing the compiled water-quality data from 2001 through 2016.

\section{Description of Study Area}

The study area comprises the upper Blackfoot River watershed, defined here as the part of the watershed upstream of the Blackfoot Reservoir (fig. 1). The Blackfoot River is a tributary of the Snake River. The upper Blackfoot River watershed spans approximately $345 \mathrm{mi}^{2}$ and ranges in elevation from 6,100 to $8,790 \mathrm{ft}$ with a mean elevation of about 7,000 ft. In this watershed, the USGS operates one streamgage and water-quality monitoring station at Blackfoot River above reservoir near Henry, Idaho (13063000). This station is about $4.9 \mathrm{mi}$ upstream of the reservoir and captures about 97 percent of the upper Blackfoot River watershed by area. This area includes the major tributaries to the Blackfoot River and 13 mines; however, drainage from 1 operating mine, Blackfoot Bridge, occurs mostly downstream of this station (fig. 2). The Dry Valley reach seepage study area (fig. 1) is about 28 river miles upstream of the streamgage. This small reach is about $2 \mathrm{mi}$ long and the downstream-most measurement site represents a watershed of about $185 \mathrm{mi}^{2}$ or about 54 percent of the upper Blackfoot River watershed. Tributaries in the watershed often originate on the ridges and disappear into the alluvium upon reaching the valleys without surficially connecting to the valley bottom streams (fig. 1).

Sedimentary rock, primarily of marine origin, underlies the upper Blackfoot River watershed. Major formations in the area include the Wells, Phosphoria and Dinwoody. Topography in the upper Blackfoot River watershed largely follows geology, with northwest-southeast trending ridges formed roughly along fold axes. Mining tends to occur on ridges and flanks because alluvium of variable depth covers ore in the valleys. The upper Blackfoot watershed contains 13 mines, of which 3 are currently active (Bureau of Land Management and U.S. Forest Service, 2016). Mining activity extracts ore from the Meade Peak member of the Phosphoria Formation. The Meade Peak member hosts two phosphate ore zones separated and stratigraphically overlain by black "waste" shale zones. Elevated selenium concentrations occur in both the waste shales and the ore zones and averages 65 milligrams per kilogram $(\mathrm{mg} / \mathrm{kg})$ overall, compared to the average crustal abundance of about $0.05 \mathrm{mg} / \mathrm{kg}$ (Herring and Grauch, 2004). This selenium readily weathers from the rock when exposed to air and water through mining activities (Herring, 2004). 


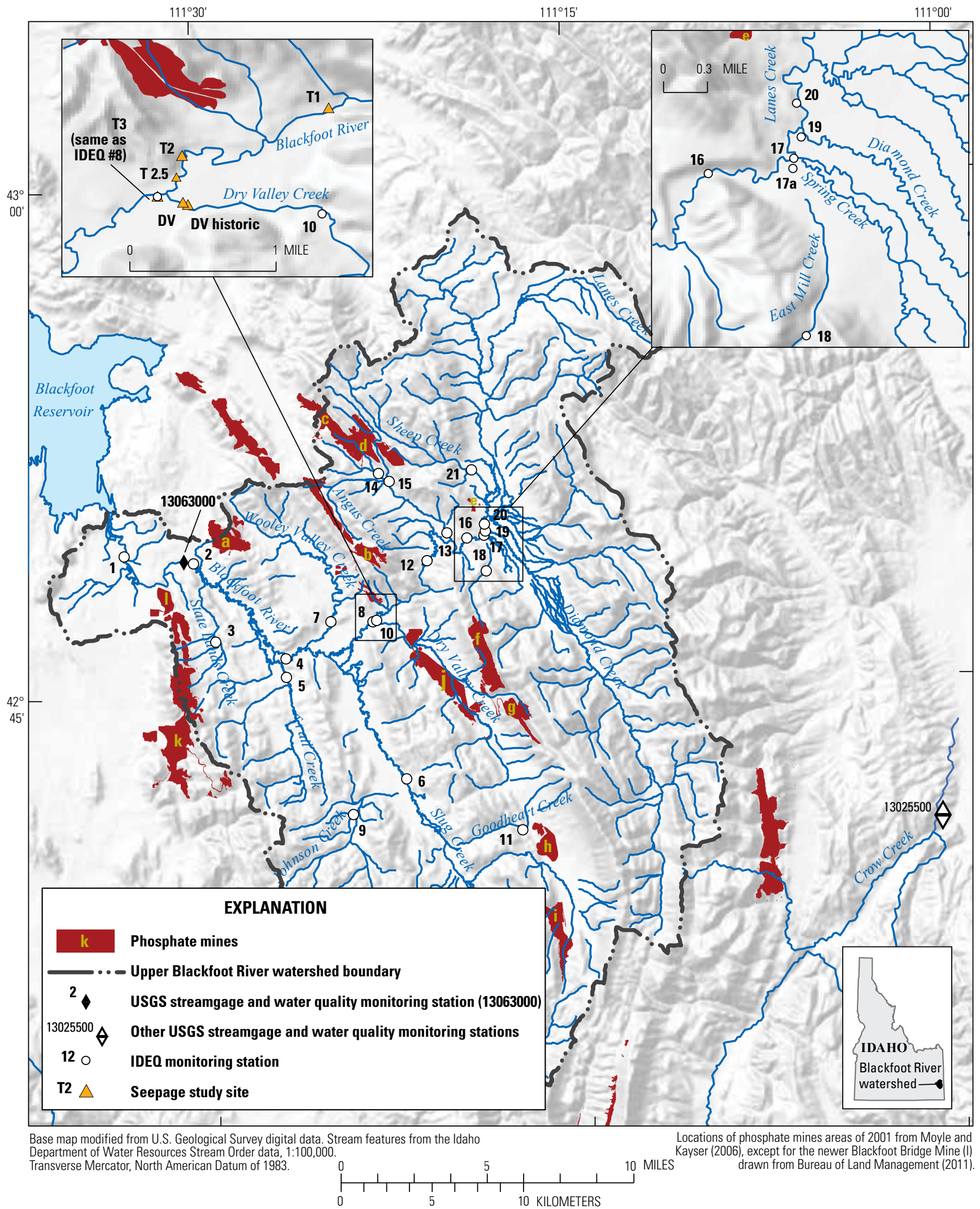

Figure 1. Phosphate mines and monitoring stations in the upper Blackfoot River watershed study area, southeastern, Idaho, 2001-16. Phosphate mines in the watershed upstream of the U.S. Geological Survey (USGS) streamgage and water quality monitoring station, Blackfoot River above reservoir near Henry (13063000), include Ballard (a), Wooley Valley (b), Enoch Valley (c), Rasmussen Ridge (d), Lanes Creek (e), Maybe Canyon North (f), Maybe Canyon South (g), Champ (h), Mountain Fuel (i), Dry Valley (j), and Conda (k). Part of the Blackfoot Bridge Mine (I) reports to the Blackfoot River downstream of USGS station 13063000. (IDEQ, Idaho Department of Environmental Quality). 
(d. Rasmussen Ridge Mine)

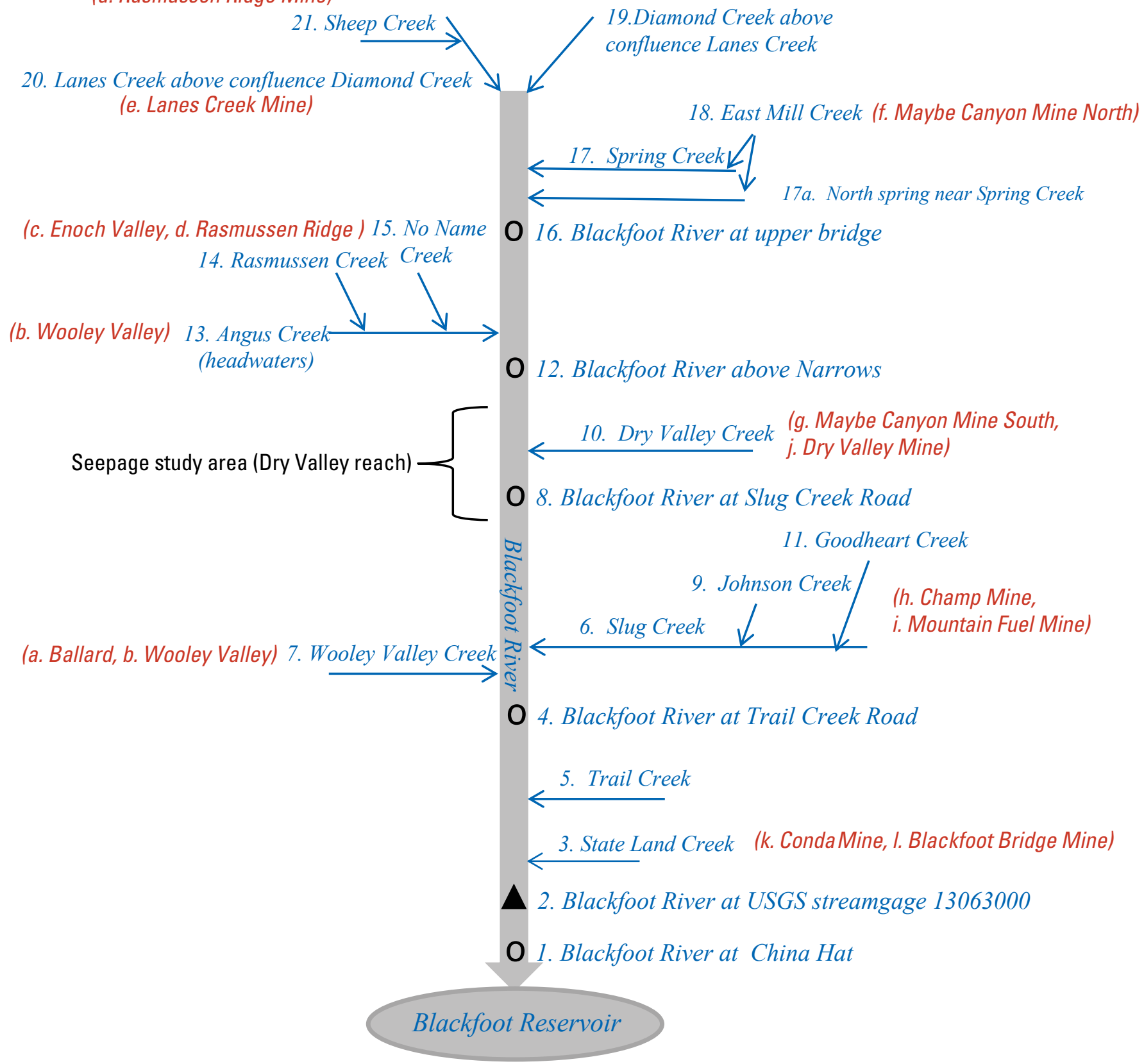

Figure 2. Hierarchy of tributaries and phosphate mines in relation to the Idaho Department of Environmental Quality (IDE0) sampling stations on the mainstem upper Blackfoot River (open circles) and tributaries, southeastern Idaho. Phosphate mines within the watersheds of different tributaries are shown in parentheses with letters; mine and site locations are shown in figure 1. 
Exposures of the Phosphoria Formation extend beyond the upper Blackfoot River watershed and, in some areas, are also associated with elevated selenium concentrations in stream drainages. For example, Crow Creek in southeastern Idaho and southwestern Wyoming receives drainage from mined areas just east of the upper Blackfoot River watershed. From 2012 to 2017, selenium concentrations in water samples from lower Crow Creek near Fairview, Wyoming (station 13025500) averaged 16 micrograms per liter $[\mu \mathrm{g} / \mathrm{L}$, range $4.9-21.2 \mu \mathrm{g} / \mathrm{L}$, $\mathrm{n}=21$; U.S. Geological Survey (2017b)].

The Wells Formation, which stratigraphically underlies the Phosphoria Formation, comprises limestone, dolomite, and sandstone, and hosts a regional aquifer whose flow paths are determined by stratigraphy and structure (Ralston and Williams, 1979). Alluvial and surficial deposits in the valleys form local, shallow aquifers. The low permeability Meade Peak member largely functions as an aquitard. The Meade Peak member is stratigraphically overlain by the Rex Chert and Cherty Shale members of the Phosphoria Formation and by the Dinwoody Formation. The Dinwoody shale and Rex Chert form sub-watershed scale aquifers within the upper Blackfoot River watershed (Ralston and Williams, 1979).

\section{Selenium in the Environment}

Previous works have shown that elevated selenium concentrations occur through aquatic food webs in miningaffected streams in the upper Blackfoot River watershed (Hamilton, 2004; Conley, 2012). Waste rock piles release selenium into aquatic ecosystems through drainage systems and subsequent periphyton uptake, and into terrestrial ecosystems through plant uptake (Hamilton and others, 2004). At low concentrations selenium is an essential micronutrient for animals but at marginally higher concentrations it can be toxic. A nonmetal, selenium behaves similarly to sulfur; toxicity of selenium occurs when biochemical pathways substitute selenium for sulfur during protein synthesis, thus altering their structure and function (Presser and Luoma, 2010).

Selenium exists in four oxidation states in the environment: elemental selenium $\left(\mathrm{Se}^{0}\right)$, selenide $\left(\mathrm{Se}^{-2}\right)$, selenite $\left(\mathrm{SeO}_{3}\right)$ and selenate $\left(\mathrm{SeO}_{4}\right)$. Selenide is insoluble in water and elemental selenium tends to be stable in reducing environments. In oxygenated waters, selenium occurs primarily as selenate, less frequently as selenite, and least frequently as organic selenium (McNeal and Balistrieri, 1989; Maher and others, 2010). Previous work on selenium speciation in the Blackfoot River showed that selenate represented a median of 80 percent of the total selenium with selenite making up the remainder. Selenate was most abundant during spring runoff conditions, whereas selenite was more abundant during late summer low flows (Mebane and others, 2015). Both of these species occur in dissolved form and dissolved selenium generally represents more than 90 percent of the total selenium in the Blackfoot River system (Presser and others, 2004a).

Prior to 2018, selenium concentrations in the study area were compared to the Idaho chronic aquatic life criterion for selenium, which was $5 \mu \mathrm{g} / \mathrm{L}$ (Idaho Department of Environmental Quality, variously dated). In 2018, site-specific aquatic life criteria were established for the upper Blackfoot River watershed. The new criteria framework is more complex and is primarily defined in terms of fish tissue concentrations (Idaho Department of Environmental Quality, 2017). Thus, selenium concentrations in water in this report are described in the context of trends and summary statistics, but are not compared to any specific concentration benchmark, for there is none. The site-specific criteria are described in more detail in section, "Future Monitoring Considerations."

\section{Methods of Investigation}

For this study, water-quality sample data and streamflow measurements were combined from three separate but related studies: (1) data collected by the USGS at Blackfoot River near Henry, Idaho (13063000), from 2001 to 2016; (2) data collected by the IDEQ in the Blackfoot River and tributaries from 2001 to 2016; and (3) data collected jointly by the USGS and IDEQ in a reach of the Blackfoot River during a June 2016 seepage study.

\section{Sampling Methods at USGS Station 13063000}

The USGS measured streamflow and concentrations of selenium and other constituents at USGS station 13063000 from 2001 through 2016. During freezing conditions (approximately October through mid-March), but when water velocity was greater than or equal to 1.5 foot per second (ft/s), water-quality samples were collected by equal width increment (EWI) methods. When water velocity was less than $1.5 \mathrm{ft} / \mathrm{s}$, grab samples were collected at the point of greatest streamflow velocity using a DH-81 sampler and Teflon ${ }^{\circledR}$ bottle without a nozzle (U.S. Geological Survey, variously dated). During non-freezing conditions (approximately 
late March through September), an ISCO model 3700 autosampler (ISCO) was used to collect samples based on the volume of water flowing past the streamgage. Generally, the ISCO collected one sample for every streamflow pulse (when 50 million $\mathrm{ft}^{3}$ of water has passed the streamgage); however, during high streamflow (spring runoff) conditions, the ISCO was generally programmed to collect one sample every other streamflow pulse. The ISCO was programmed to collect samples according to streamflow pulses so that more samples would be collected during spring runoff and fewer samples during summer low streamflow conditions, and the optimal pulse volume was determined iteratively. Autosamples were retrieved from the ISCO every 2-3 weeks. Samples were filtered using a 0.45 micrometer pore-size disposable capsule filter, preserved with nitric acid, and sent to the USGS National Water Quality Laboratory for analysis of major ions, selenium, and other selected trace elements. Equipment components that contacted samples were cleaned with Liquinox ${ }^{\circledR}$ detergent, soaked in a 5 percent hydrochloric acid solution, and rinsed with deionized water prior to use.

From 2001 to 2005, selenium concentrations were measured by inductively coupled plasma-mass spectrometry, which has a method detection limit of about $0.1 \mu \mathrm{g} / \mathrm{L}$ (Garbarino, 1999). From 2006 to 2016, selenium concentrations were measured by collision/reaction cell inductively coupled plasma-mass spectrometry, which has a method detection limit of about $0.03 \mu \mathrm{g} / \mathrm{L}$ (Garbarino and others, 2006). Previous work has indicated that most selenium in the Blackfoot River is dissolved (Presser and others, 2004a; Mebane and others, 2015); therefore, for this study, dissolved selenium samples were primarily measured. However, a limited number of total selenium analyses were completed from 2012 to 2014 and these data $(n=22)$ were combined with the dissolved selenium results $(\mathrm{n}=481)$ for the analyses presented in this report. Where both dissolved and total sample selenium analyses were available for a single date $(n=3)$, dissolved analyses were preferentially selected for analysis. Finally, where replicate samples were available for a single date ( $\mathrm{n}=219$ total on 85 individual dates), only the parent sample was selected for statistical analysis.

Data quality of the water-quality analyses for this study was evaluated using several types of quality control samples (Mueller and others, 2015). First, the USGS National Water Quality Laboratory performance was examined through regular testing of inorganic blind samples and through semiannual interlaboratory testing of standard reference samples. Second, ambient blanks were used to evaluate atmospheric cross-contamination of samples in the autosampler housing. Third, equipment blanks were used to assess the effectiveness of equipment cleaning procedures. Fourth, grab samples collected concurrently with autosamples (concurrent replicates) were used to determine if autosample composition was affected by the autosampler pump intake mechanism. Fifth, grab sample replicates were collected to determine variability of grab sampling. Lastly, EWI samples collected concurrently with autosamples (concurrent replicates) were used to evaluate how well autosamples represented the entire river cross section. The quality control samples were collected according to the protocols detailed by the U.S. Geological Survey (variously dated).

\section{Watershed-Wide Sampling Methods}

In contrast to the USGS, whose sampling efforts focused on a single, watershed-integrating site sampled year-round, the IDEQ sampled 21 sites on the Blackfoot River mainstem and tributaries (fig. 2) annually during spring runoff conditions from 2001 to 2016. Field crews followed USGS sampling and processing methods (U.S. Geological Survey, variously dated). Water-quality samples were collected using width- and depth-integrated sampling methods; these included using depth-integrating samplers from bridgeboards or long rods from bridges when streams were not wadable and using handheld depth-integrating samplers in wadable conditions. Samples were subsequently stored in polyethylene containers and preserved with nitric acid. The IDEQ targeted 4-day sampling periods, during which time three samples from each site were collected and composited. This strategy allowed direct comparison to the pre-2018 State of Idaho chronic selenium standard which was expressed as a 4-day average concentration. Equipment that contacted water-quality samples was washed with Alconox ${ }^{\circledR}$ detergent and triple-rinsed with deionized water and then rinsed with sample water between successive samples. The IDEQ samples were processed by ACZ Laboratories (Steamboat Springs, Colorado) from 2001 to 2008, and by SVL Analytical (Kellogg, Idaho) from 2009 to 2016. Both laboratories analyzed total selenium either by Standard Method 3114B, hydride generation and atomic absorption (Eaton and others, 2005) or U.S. Environmental Protection Agency method 6020A (U.S. Environmental Protection Agency, 1998). Both laboratories reported detection limits averaging $2 \mu \mathrm{g} / \mathrm{L}$ but ranging from 1 to $5 \mu \mathrm{g} / \mathrm{L}$. 
In addition to regular samples, quality control samples including split replicates, ambient blanks, and equipment blanks were collected concurrently with field samples to assess data quality. Split replicate samples were collected as a single composite sample collected in the field and subsequently split into two subsamples for separate analysis. Ambient blanks were collected by pouring deionized water directly into sample bottles in the field. Equipment blanks were collected by processing deionized water through the sampling equipment after cleaning.

In smaller streams, IDEQ measured instantaneous streamflow using a Marsh-McBirney model 2000 portable electromagnetic streamflow meter and a top-setting wading rod. In larger streams, an acoustic Doppler current profiler was used to measure streamflow. Streamflow was measured on day one and day four of the sampling period; mean streamflow for this period was calculated by averaging the two measurements. Low streamflows were estimated visually at the threshold of less than 0.25 cubic feet per second $\left(\mathrm{ft}^{3} / \mathrm{s}\right)$; streamflow was measured at sites with flows higher than this threshold.

\section{Dry Valley Reach Seepage Study Sampling Methods}

\section{Site Evaluation}

In June 2016, USGS and IDEQ jointly conducted a seepage study in a targeted reach of the Blackfoot River between the Narrows and the confluence with Dry Valley Creek (fig. 1). Seepage study refers to a methodology in which streamflow is measured at multiple locations in a stream, and streamflow gains or losses between locations are inferred to indicate groundwater exchange (Riggs, 1972). A longitudinal profile of water-quality parameters along the reach was collected as a preliminary site evaluation on June 20, 2016, to determine the placement of streamflow and water-quality sampling sites. A global position system (GPS) unit and a water-quality sonde measuring specific conductance, $\mathrm{pH}$, and dissolved oxygen, were mounted on a kayak to identify locations along the stream reach where changing water-quality conditions might indicate potential groundwater inflow.

Based on this preliminary evaluation, three transects were established. T1 was at the upstream end of the reach, just downstream of the Narrows; T2 was about two-thirds of the way downstream in the reach, where the Blackfoot River is near Blackfoot River Road; and T3 was at the downstream end of the reach, below the confluence of Dry Valley Creek and the Slug Creek Road bridge (fig. 1). Streamflow measurements and water-quality samples were collected at these sites on June 21, 22, and 23. Additionally, a fourth site, T2.5, was approximately halfway between sites $\mathrm{T} 2$ and $\mathrm{T} 3$ and upstream of the railroad bridge; streamflow and water-quality samples were collected at T2.5 site on June 22 and 23. Samples and streamflow measurements were also collected at the mouth of Dry Valley Creek (site DV, fig. 1) on all three days, and at the mouth of the historical Dry Valley Creek channel on June 21. The current Dry Valley Creek channel is not the original channel configuration; Dry Valley Creek was straightened along the north margin of the railroad spur in the mid-1960s. The historical Dry Valley Creek channel is on the southern margin of the railroad spur and is no longer surficially connected to the Dry Valley Creek drainage.

\section{Streamflow and Sampling Methods}

Samples were collected, processed and analyzed for selenium at each site in accordance with the EWI methods previously described for USGS station 13063000 and the methods described in U.S. Geological Survey (variously dated). Split replicates were collected and sent to USGS National Water Quality Laboratory and SVL Analytical to compare analytical performance between laboratories used by USGS and IDEQ, respectively (Mueller and others, 2015). Streamflow measurements were taken in accordance with USGS Office of Surface Water protocols, policies, and published guidance (Oberg and others, 2005; Sauer and Turnipseed, 2010).

The YSI SonTek ${ }^{\circledR}$ FlowTracker handheld acoustic Doppler velocimeters and top-setting wading rods were used to make streamflow measurements. Geographic coordinates provided for the measurement sites were based on a handheld GPS, using the horizontal coordinate information of the North American Datum of 1983. Streamflow measurements were completed at each site on each day, excepting the historical channel of Dry Valley Creek. The streamflow at this site was low $\left(0.045 \mathrm{ft}^{3} / \mathrm{s}\right.$ on June 21$)$ and stable, and therefore was estimated at the same streamflow $\left(0.045 \mathrm{ft}^{3} / \mathrm{s}\right)$ on subsequent days. Temporary stage gages were installed at the upstream and downstream ends of the reach. Pressure transducers were suspended in PVC housing and secured to a fixed point and collocated with staff gages. These data were collected to provide a relative sense of streamflow stability during the study duration but were not used to measure absolute streamflow rates. 
During the seepage study, streamflow measurements were made at sites along the mainstem of the river and at each significant inflow; no outflows were seen or measured along the study reach. The increase or decrease in the streamflow between mainstem measurement sites that could not be attributed to inflows or outflows (and ignoring evapotranspiration losses, which were expected to be small) represented an estimate of the net flow interchange between surface water and groundwater. The mass balance equation used for determining this estimate is as follows (Simonds and Sinclair, 2002):

Net flow gain or loss $=Q_{d}-T-Q_{u}+D$,

where

$Q_{d} \quad$ is the streamflow measured at the downstream end of the reach, in cubic feet per second;

$Q_{u} \quad$ is the streamflow measured at the upstream end of the reach, in cubic feet per second;

$T \quad$ is the sum of tributary inflows, in cubic feet per second, and

$D \quad$ is the sum of the diversion outflows, in cubic feet per second.

Thus, the equation estimated the net change, in cubic feet per second, in the streamflow through a reach, where positive values indicated a gaining reach and negative values indicated a losing reach.

\section{Estimates of Uncertainty}

The FlowTracker acoustic Doppler velocimeter internally calculates an uncertainty value through a statistical technique developed by the USGS (U.S. Geological Survey, 2017a). Because net gain or loss is calculated from two or more measurements, the uncertainty from each measurement must be propagated to determine the uncertainty inherent in the net gain or loss. The propagated uncertainty was calculated according to the following formula (Wheeler and Eddy-Miller, 2005):

$$
s=\sqrt{( \pm a)^{2}+( \pm b)^{2} \ldots+( \pm n)^{2}}
$$

where

\footnotetext{
$s \quad$ is the error propagated from all estimated individual errors, and

$a, b, \ldots, n \quad$ are the estimated errors for the streamflow

$a, b, \ldots, n \quad$ measurement at each site.
}

\section{Other Data}

In addition to data collected by the USGS and IDEQ, some data collected by other entities are used in this report. Precipitation data, including water year total precipitation and snow water equivalent, was obtained from the Somsen Ranch and Slug Creek Divide SNOTEL stations which are operated by the U.S. Department of Agriculture, Natural Resources Conservation Service (Natural Resources Conservation Service, 2017a; 2017b). The Somsen Ranch station is near the upper northeastern bound of the upper Blackfoot River watershed at an elevation of about $6,800 \mathrm{ft}$. The Slug Creek Divide station is about midway along the southern margin of the watershed at an elevation of about 7,225 ft. In the Blackfoot River watershed, which averages 7,000 ft, elevation strongly influences precipitation and snow accumulation. Therefore, precipitation data from both stations were averaged for analysis to better represent the overall conditions of the watershed.

Precipitation indices were calculated at each station then averaged together. Total precipitation was defined as the cumulative precipitation total for each water year. Total snow water equivalent was defined as the maximum cumulative snow water equivalent value for each water year. Runoff precipitation was the sum of precipitation occurring during April and May. Therefore, if the maximum cumulative snow water equivalent occurred in April or May, it is possible that some precipitation may be double counted for a given year as both snow water equivalent and runoff precipitation. However, this amount of precipitation is expected to be small because maximum cumulative snow water equivalent occurs during March in most years.

The IDEQ tributary data for Dry Valley Creek were supplemented with data from Whetstone Associates (2017). Whetstone Associates collected more samples from Dry Valley Creek from 2001 to 2016 than IDEQ, and including these data allowed a greater range of concentrations and conditions to be included in the analysis. These data were collected consistent with the methods used by IDEQ as previously described (Whetstone Associates, 2017). 


\section{Statistical Interpretations}

\section{Concentrations Versus Loads}

In this report, selenium is reported as concentrations and loads; both are useful for analyzing data in different ways. Concentrations (mass per unit volume) are directly measured and are useful for assessing water-quality based standard and criteria. Loads (mass per unit time) are useful for assessing sources and sinks of selenium on a watershed-wide basis as well as for evaluating the mass transport of selenium to downstream waters. Selenium loads were calculated using point-in-time concentrations and streamflows. Daily selenium loads, in kilograms per day $(\mathrm{kg} / \mathrm{d})$, were estimated according to the following formula:

$$
\operatorname{Load}\left(\frac{\mathrm{kg}}{\mathrm{d}}\right)=Q \times C \times 2.447,
$$

where

$$
\begin{aligned}
& Q \quad \text { is streamflow, in } \mathrm{ft}^{3} / \mathrm{s}, \\
& \text { is concentration, in } \mathrm{mg} / \mathrm{L} \text {, and } 2.447 \text { is a unit } \\
& \text { conversion constant for calculating daily } \\
& \text { load. }
\end{aligned}
$$

For daily load calculations made at the USGS station 13063000 , loads were calculated using point-intime concentrations and daily average streamflow. For watershed wide and seepage load calculations, point-in-time concentrations and measured instantaneous streamflows were used to calculate instantaneous loads. Instantaneous loads were then extrapolated to a daily load by assuming the streamflow and chemistry remained constant through the day.

\section{Statistical Methods}

Statistical methods used to analyze the water-quality data are primarily descriptive. Methods used included data graphing, descriptions of centrality and variance, and analytical approaches to dampen seasonal influences and outlier data including locally weighted scatterplot smoothing (LOESS; Cleveland and others, 1992). Spearman's rho was used to describe correlations between streamflow and concentration; because it is nonparametric, Spearman's rho is useful for detecting monotonic correlations between two variables without requiring them to be linear or transformed. Non-linear techniques are imperative for evaluating streamflow and datasets of selenium concentration, which can have small sample sizes (for some tributaries), be rightskewed, and often exhibit a log normal data distribution.

Because USGS station 13063000 was operated only seasonally since 2006, MOVE.1 methods (Hirsch, 1982; Granato, 2009) were used to create an estimated, or synthetic, daily streamflow record for times when the streamgage was not operating. MOVE. 1 is a maintenance of variance method that uses a nearby streamgage with a complete streamflow record (in this case, USGS station 13027500, Salt River above reservoir near Etna, Wyoming) to estimate a complete record at a station of interest (in this case, USGS station 13063000). Although a complete streamflow record was useful for some analyses, daily average measurement values were used whenever they were available and estimated streamflow data were used only in the absence of daily values.

\section{Selenium in the Upper Blackfoot River Watershed}

The results presented in this report focus on selenium although multiple other water-quality constituents also have been measured and are available through the National Water Information System website, https://waterdata.usgs.gov/nwis, (U.S. Geological Survey, 2017b). Note that water-quality concentrations are reported herein with the significant figures provided by the laboratory. Thus, concentrations are consistent with reported analytical precision (which varied by laboratory and over time) but significant figures are not necessarily the same for all results.

\section{Data Quality}

The data quality evaluations are discussed here in brief; appendix 1 contains a more detailed discussion of these results. Evaluations of USGS data quality showed no evidence of field or laboratory contamination of samples, with no selenium detections in any of 15 ambient and equipment blanks collected between 2013 and 2016. Analysis of the concurrent replicate samples collected from 2013 to 2016 by autosampler, EWI, and grab methods showed similar concentrations indicating that the autosampler adequately represented the river cross section concentrations. The median relative sample deviation (RSD) was 2.8 percent, ranging from 0 to only 6.9 percent in the 13 concurrent replicate pairs (appendix 1).

Equipment and ambient blanks collected by IDEQ similarly showed no evidence of field contamination of samples, with no selenium detections in any of the 19 equipment and ambient blanks collected between 2001 and 2016. Split replicate sample results were generally in good agreement with RSD less than 20 percent for selenium in 21 of 23 split replicate pairs collected from 2001 to 2016. One split replicate pair from upper Angus Creek and one pair from the Blackfoot River above Narrows exceeded 50 percent RSD in 2004 and 2005 respectively. 
The inherent accuracy and bias of the laboratory analyses was evaluated through examining internal inorganic blind sample results and interlaboratory standard reference sample evaluations conducted by the USGS Bureau of Quality Systems and by Environment Canada. The evaluation showed a persistent low bias for selenium concentrations less than about $0.5 \mu \mathrm{g} / \mathrm{L}$, and a slight high bias in concentrations greater than about $30 \mu \mathrm{g} / \mathrm{L}$. Within the range of selenium concentrations most relevant to this study (about $1-10 \mu \mathrm{g} / \mathrm{L}$ ), the results of performance testing were linear and within acceptable bounds. A more detailed analysis of these results is presented in appendix 1.

Specific to this project, six pairs of split replicate samples were collected during the seepage study and analyzed separately for selenium by the USGS National Water Quality Laboratory and by the laboratory used to analyze the IDEQ samples (SVL Analytical). The agreement between the National Water Quality Laboratory and SVL Analytical results was good, with a median RSD of 4.1 percent and a range of 1.3-12.3 percent for the split samples (appendix 1). Overall, the data quality results indicate that the data collected for this study accurately characterize selenium concentrations in the study area and are thus suitable for evaluations in the following sections.

\section{Temporal Patterns and Trends in Selenium Concentrations}

Selenium was detected in each of the 635 water samples collected by the USGS at station 13063000 between 2001 and 2016 and concentrations ranged from a minimum of $0.5 \mu \mathrm{g} / \mathrm{L}$ to a maximum of $13.8 \mu \mathrm{g} / \mathrm{L}$ with a median concentration of $2.7 \mu \mathrm{g} / \mathrm{L}$ (U.S. Geological Survey, 2017b). In general, selenium concentration correlated with streamflow (Spearman's rho $=0.605, \mathrm{p}=0, \mathrm{n}=500$ ). More specifically, selenium concentrations tended to be highest during and shortly following peak streamflow, decreased during the hydrograph recession, and remained relatively stable and low during late summer and early autumn baseflow conditions (fig. 3). During runoff conditions (defined herein as streamflows in April and May), selenium concentrations ranged from 1 to $13.8 \mu \mathrm{g} / \mathrm{L}$ and had a median concentration of $4.1 \mu \mathrm{g} / \mathrm{L}(\mathrm{n}=308)$. During baseflow conditions (defined herein as streamflows in August, September and October), selenium concentrations ranged from $0.5 \mu \mathrm{g} / \mathrm{L}$ to $3 \mu \mathrm{g} / \mathrm{L}$, with a median concentration of $1.5 \mu \mathrm{g} / \mathrm{L}(\mathrm{n}=66)$. In comparison, IDEQ reported a median total selenium concentration of $0.14 \mu \mathrm{g} / \mathrm{L}$ in 34 samples collected as part of a statewide survey of large rivers (Essig, 2010).

Mebane and others (2015) compared 2001 to 2012 water-quality data to established State of Idaho and federal water-quality criteria at that time. For the years added to the record (2013-16) and included in this report, various summary statistics were calculated, including arithmetic averages, minimums, maximums, time-weighted averages (calculated for March 1 through September 30, approximately when the autosampler operated), and maximum 4- and 30-day moving average selenium concentrations (table 1). Each year, the single measured maximum selenium concentration was equal to or higher than the 4-day moving average and the 4-day moving average was higher than the 30 -day moving average. This outcome is expected, given that selenium concentrations tend to peak and decline relatively quickly in concert with peak streamflow in the Blackfoot River, and longer averaging periods will include more samples collected outside of the peak streamflow times (fig. 3).

As reported in Mebane and others (2015), the relationship between selenium concentration and streamflow is complex (fig. 4). The highest selenium concentrations generally lagged peak streamflow by as little as 2 days to as long as 36 days, with a median lag in the peak selenium concentration of 15 days after peak streamflow. However, there were some exceptions to this generality. For example, in 2015, the peak selenium concentration of $5.6 \mu \mathrm{g} / \mathrm{L}$ occurred 25 days after an early April secondary peak in streamflow of $300 \mathrm{ft}^{3} / \mathrm{s}$, but before the annual peak streamflow of $418 \mathrm{ft}^{3} / \mathrm{s}$ in late May.

In general, the relative magnitude of the annual peak selenium concentration correlated to the relative magnitude of the annual peak streamflow. For instance, high runoff streamflows (peak around 1,200 ft $3 / \mathrm{s}$ ) corresponded with high selenium concentrations $(12 \mu \mathrm{g} / \mathrm{L})$ in 2009 , and low runoff streamflows (peak around $500 \mathrm{ft}^{3} / \mathrm{s}$ ) corresponded with low selenium concentrations ( $4 \mu \mathrm{g} / \mathrm{L}$ ) in 2012 (fig. 4). However, there were exceptions to this general relationship. For example, a relatively high peak streamflow in 2011 (about 1,600 ft $3 / \mathrm{s}$ ) occurred with a relatively low peak selenium concentration (about $9 \mu \mathrm{g} / \mathrm{L}$ ). Conversely, a relatively low peak streamflow of about $400 \mathrm{ft}^{3} / \mathrm{s}$ in 2013 occurred with a peak selenium concentration of $13.8 \mu \mathrm{g} / \mathrm{L}$, the highest concentration measured at USGS streamgage 13063000 (fig. 4). 


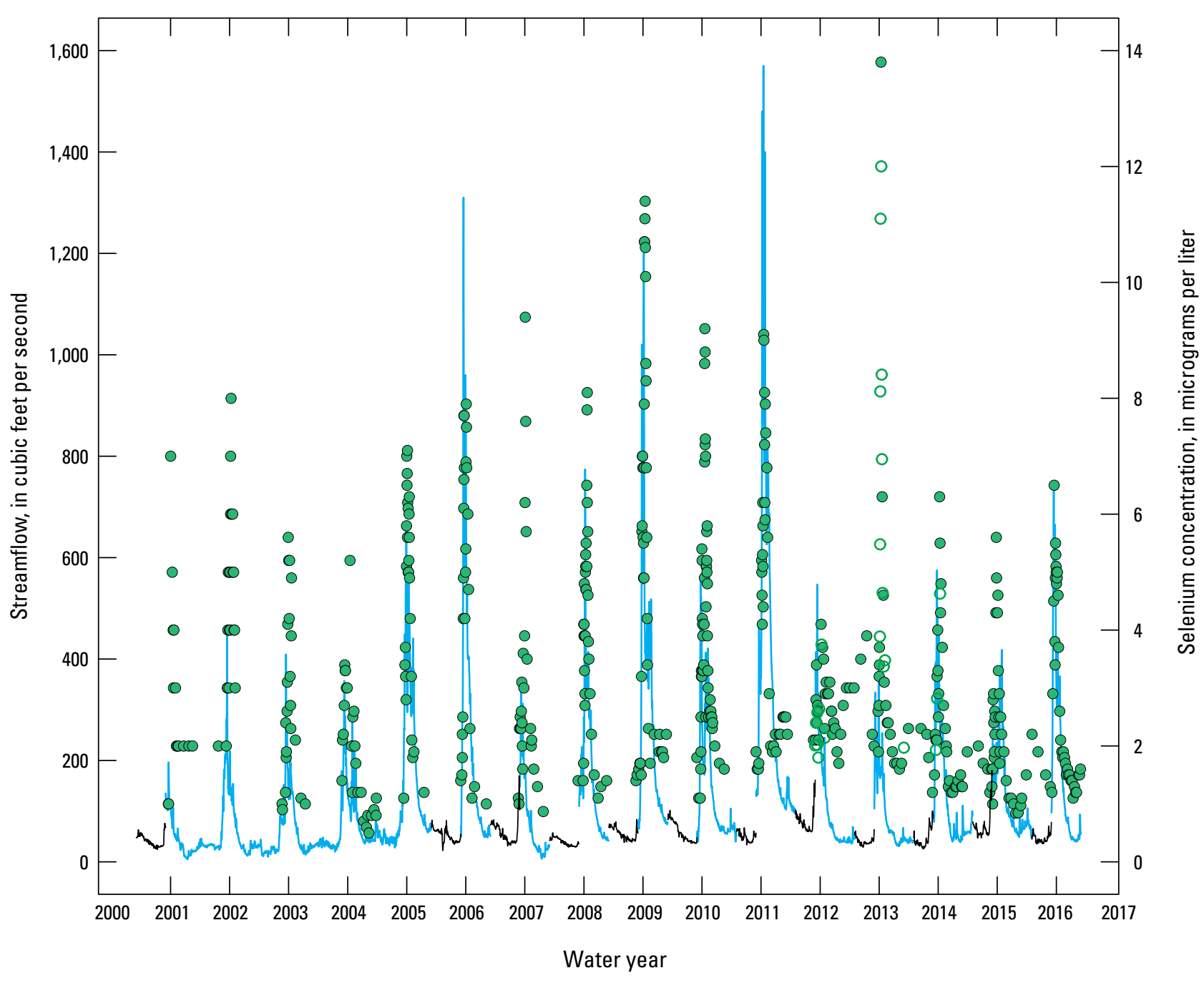

EXPLANATION

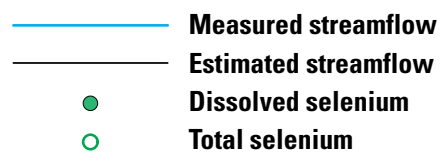

Figure 3. Selenium concentration (total and dissolved) and streamflow in the Blackfoot River above reservoir near Henry, Idaho (13063000), 2001-16. Water year labels are centered on May 1.

Table 1. Annual summaries of selenium concentrations (total and dissolved data included) collected by autosampler at U.S. Geological Survey streamgage, Blackfoot River above Reservoir near Henry, Idaho (13063000), 2013-16.

[Original data are available from U.S. Geological Survey (2017b). Abbreviations: Se, selenium; $\mu \mathrm{g} / \mathrm{L}$, microgram per liter]

\begin{tabular}{lrrrr}
\hline & \multicolumn{4}{c}{ Water Year } \\
\cline { 2 - 5 } & $\mathbf{2 0 1 3}$ & $\mathbf{2 0 1 4}$ & $\mathbf{2 0 1 5}$ & $\mathbf{2 0 1 6}$ \\
\hline Minimum Se $(\mu \mathrm{g} / \mathrm{L})$ & 1.6 & 1.2 & 0.84 & 1.1 \\
Mean Se $(\mu \mathrm{g} / \mathrm{L})$ & 4.2 & 2.4 & 2.2 & 2.7 \\
Maximum Se $(\mu \mathrm{g} / \mathrm{L})$ & 13.8 & 6.3 & 5.6 & 6.5 \\
Maximum 4-day moving average Se $(\mu \mathrm{g} / \mathrm{L})$ & 12.9 & 6.3 & 5.3 & 6.5 \\
Maximum 30-day moving average Se $(\mu \mathrm{g} / \mathrm{L})$ & 7.3 & 4.6 & 3.7 & 4.9 \\
March 1-September 30 time-weighted average selenium $(\mu \mathrm{g} / \mathrm{L})$ & 2.9 & 2.1 & 1.8 & 2.1 \\
Number of samples per year & 37 & 33 & 38 & 41 \\
\hline
\end{tabular}




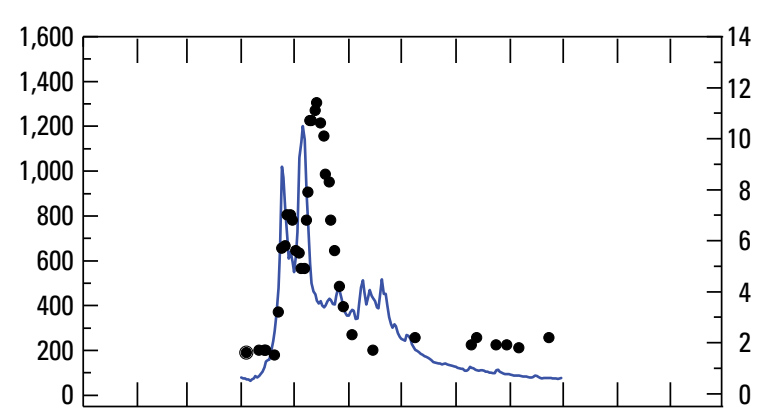

Jan. Feb. Mar. Apr. MayJuneJuly Aug. Sept.Oct. Nov. Dec. 2009
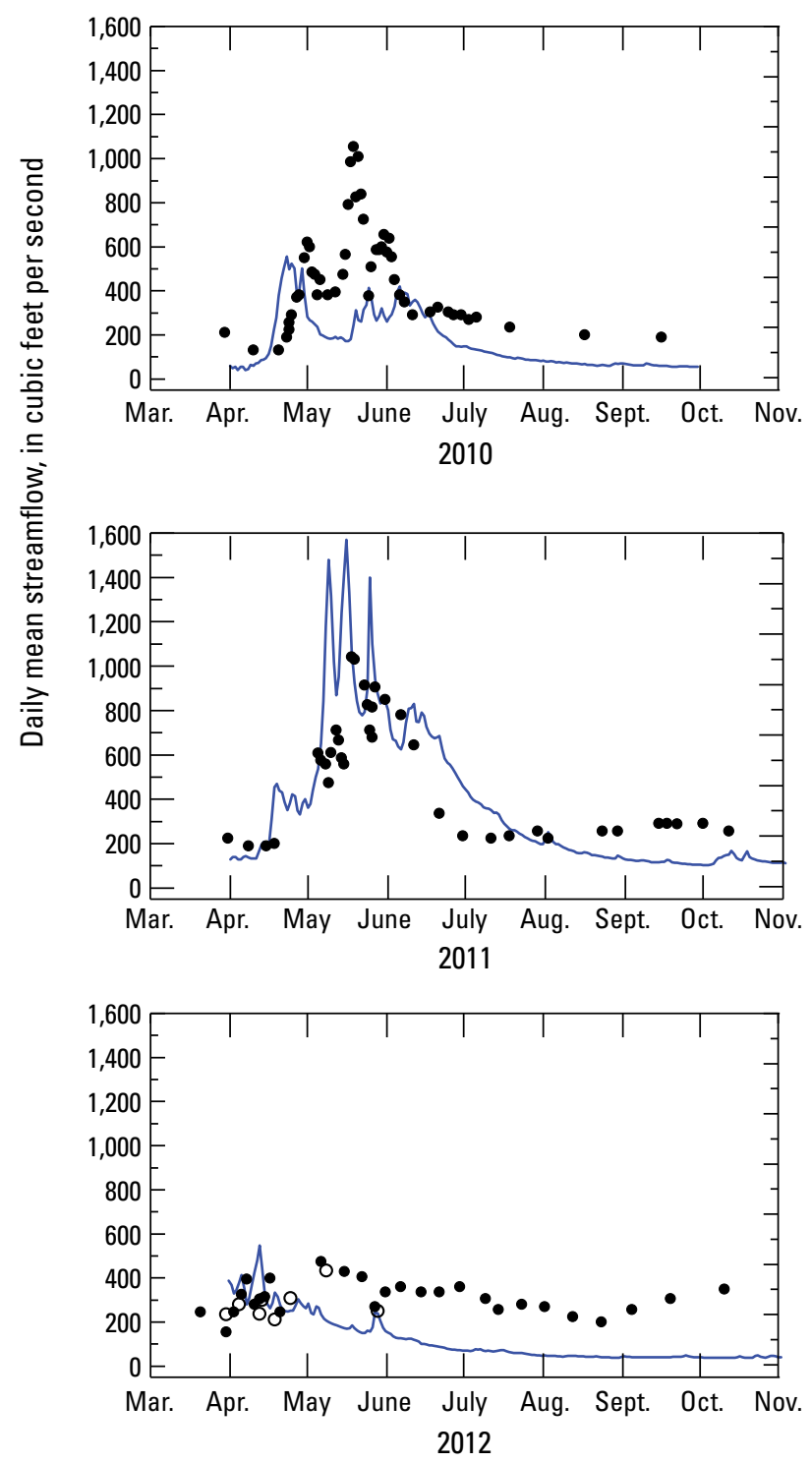

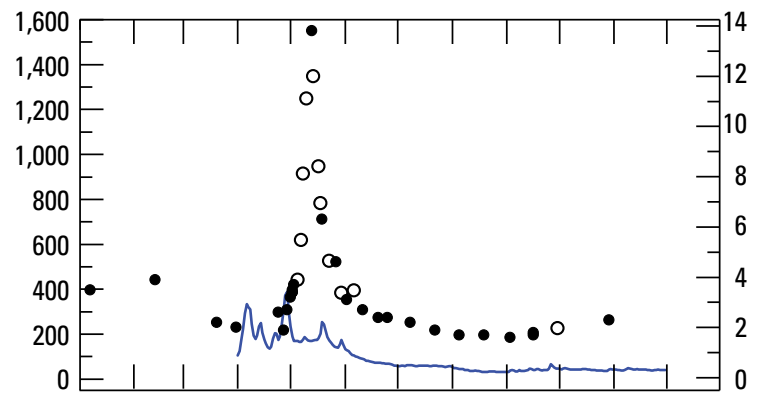

Jan. Feb. Mar. Apr. May JuneJuly Aug. Sept.Oct. Nov. Dec.

2013

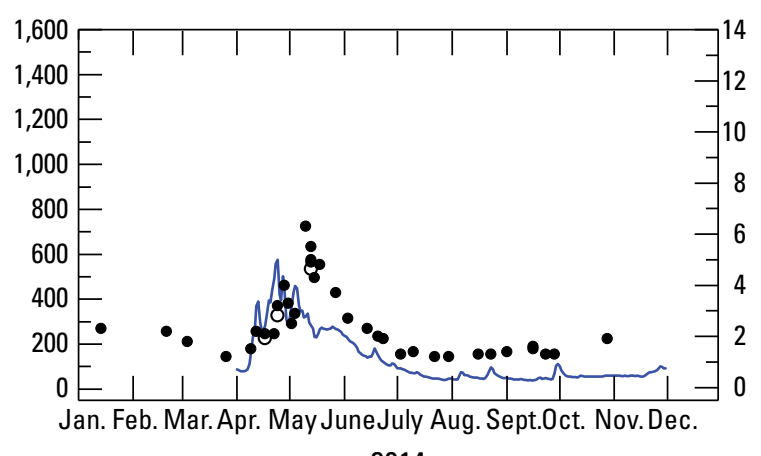

2014

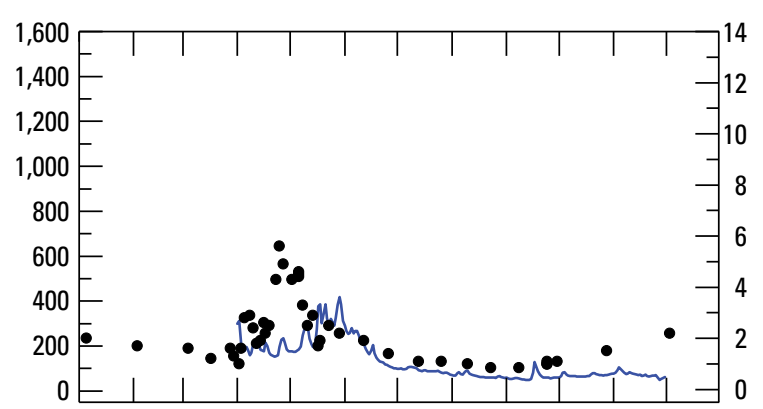

Jan. Feb. Mar. Apr. May June July Aug. Sept.Oct. Nov. Dec.

2015

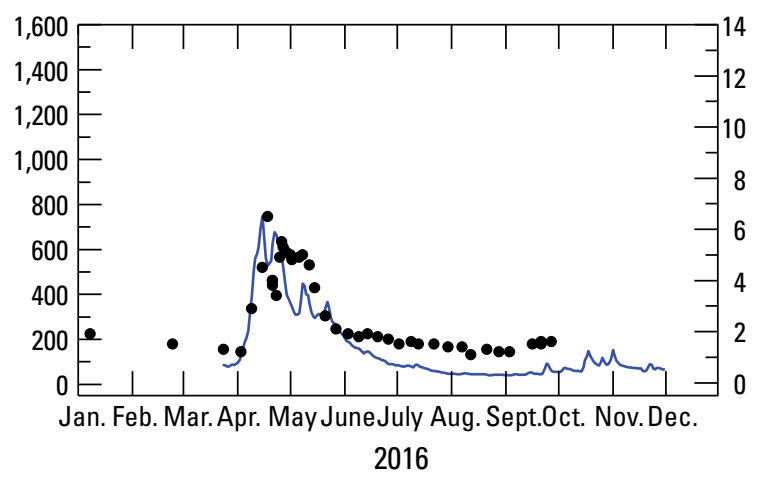

\section{EXPLANATION}

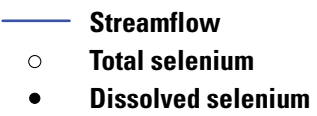

Figure 4. Annual patterns of selenium concentrations (total and dissolved) and streamflow in the Blackfoot River above reservoir near Henry, Idaho (13063000), calendar year 2009-16. 
From 2005 to 2011 median runoff selenium concentrations were higher than the long-term runoff median $(4.1 \mu \mathrm{g} / \mathrm{L})$ in every year except 2007 (fig. 5). The LOESS regression on the runoff selenium concentrations over this period similarly indicated increasing concentrations from 2001 to 2008 and decreasing concentrations from 2009 to 2016 (fig. 6). The period of high concentrations in the middle of the study generally coincided with high snowpack years (that is, higher than the 30 -year median total snow water equivalent calculated for 1981-2010, fig. 7). The 2006, 2008, 2009, and 2011 water years all had higher than median total snow water equivalent (fig. 7) and corresponded with higher than median selenium concentrations (fig. 5). However, the association of higher selenium with higher snow water equivalent and runoff does not hold for all years. For example, 2007 and 2010 water years had below median snow water equivalent, but relatively high maximum selenium concentrations. This may indicate that both the current year snowpack and the snowpack of the previous year may be important for the mobilization of selenium within the Blackfoot River watershed. Similarly, 2014 had higher than median snowpack but relatively low selenium concentrations, possibly due to low snowpack in the preceding years. In contrast, 2012 and 2013 had relatively low snowpack but the 2013 selenium concentrations included the highest measured during this study at USGS station 13063000 (fig. 1).

Although runoff selenium concentrations were elevated from 2005 to 2011, median baseflow selenium concentrations were higher than the long-term baseflow median $(1.5 \mu \mathrm{g} / \mathrm{L})$ from 2009 to 2013 (fig. 5). The LOESS regression on baseflow selenium concentrations indicated increasing concentrations from 2001 to 2012 and decreasing concentrations from 2013 to 2016 (fig. 6). This contrasts with runoff flows where the LOESS trend inflection point was 2008 (fig. 6). Notably, both the baseflow and runoff LOESS regressions indicate that the apparent monotonic increasing trend in selenium concentrations from 2001 to 2012, as noted by Mebane and others (2015), changed direction in the extended analysis period (2001-16).

\section{Spatial Patterns and Trends in Selenium Concentrations and Loads}

The USGS sampling at station 13063000 provides temporal data for selenium concentrations in the Blackfoot River, whereas the IDEQ annual runoff sampling (2001-16), provides spatial data for selenium concentrations throughout the mainstem and tributaries in the Blackfoot River watershed. Starting near the upstream part of the watershed at Sheep Creek (figs. 1 and 2), selenium concentrations in the IDEQ dataset ranged from non-detected at $<1.0$ to $9 \mu \mathrm{g} / \mathrm{L}$ and were consistently about $1 \mu \mathrm{g} / \mathrm{L}$ in Lanes Creek and Diamond Creek (fig. 7; Mladenka and others, 2018). Selenium concentrations in East Mill Creek were consistently high, ranging from 212 to $870 \mu \mathrm{g} / \mathrm{L}$, and in Spring Creek (which receives streamflow from East Mill Creek) selenium concentrations ranged from 12.3 to $69 \mu \mathrm{g} / \mathrm{L}$. Downstream of the Spring Creek confluence, the Blackfoot River had selenium concentrations ranging from 3 to $8.7 \mu \mathrm{g} / \mathrm{L}$; selenium in the Blackfoot River remained at about this concentration in the remainder of the downstream sites despite the addition of streamflow from several tributaries (fig. 8).

The downstream tributaries Rasmussen Creek, Angus Creek, Goodheart Creek, Dry Valley Creek, Wooley Creek and Slug Creek, each showed high variability in selenium concentrations. Rasmussen Creek ranged from less than 1.0 to $14.2 \mu \mathrm{g} / \mathrm{L}$, and Angus Creek ranged from 0.46 to $39 \mu \mathrm{g} / \mathrm{L}$. Dry Valley Creek and Goodheart Creek tended to have high, although still variable, selenium concentrations ranging from 4 to $119 \mu \mathrm{g} / \mathrm{L}$ and 2 to $91.6 \mu \mathrm{g} / \mathrm{L}$, respectively. Selenium concentrations in Wooley Valley Creek and Slug Creek were low, ranging from less than 1.0 to $12.77 \mu \mathrm{g} / \mathrm{L}$ and less than 1.0 to $7.95 \mu \mathrm{g} / \mathrm{L}$, respectively (fig. 8 ).

Many of the highest concentrations of selenium in both the mainstem and tributary sites were measured in years with high streamflows and high snowpack, particularly 2009 and 2011 (figs. 3, 7, and 9). However, the mainstem sites and Spring Creek also had high concentrations of selenium in 2013, which was a relatively low streamflow year and had neither a high snow pack nor high precipitation. Like USGS station 13063000, many of the IDEQ tributary and mainstem sites have statistically significant (Spearman's rho, p-value $<0.10$ ) correlations between streamflow and selenium concentration (table 2). These include sites on Rasmussen Creek, Dry Valley Creek, Goodheart Creek, Sheep Creek, East Mill Creek, State Land Creek, Wooley Valley Creek and Lanes Creek. Each of these creeks have upstream mining disturbance. The strength and shape of these relationships varies between tributaries (table 2), suggesting that factors such as the type and location of mine waste piles, amount of snow accumulation, and nature of water movement through a site likely influence how and to what extent runoff mobilizes selenium. 

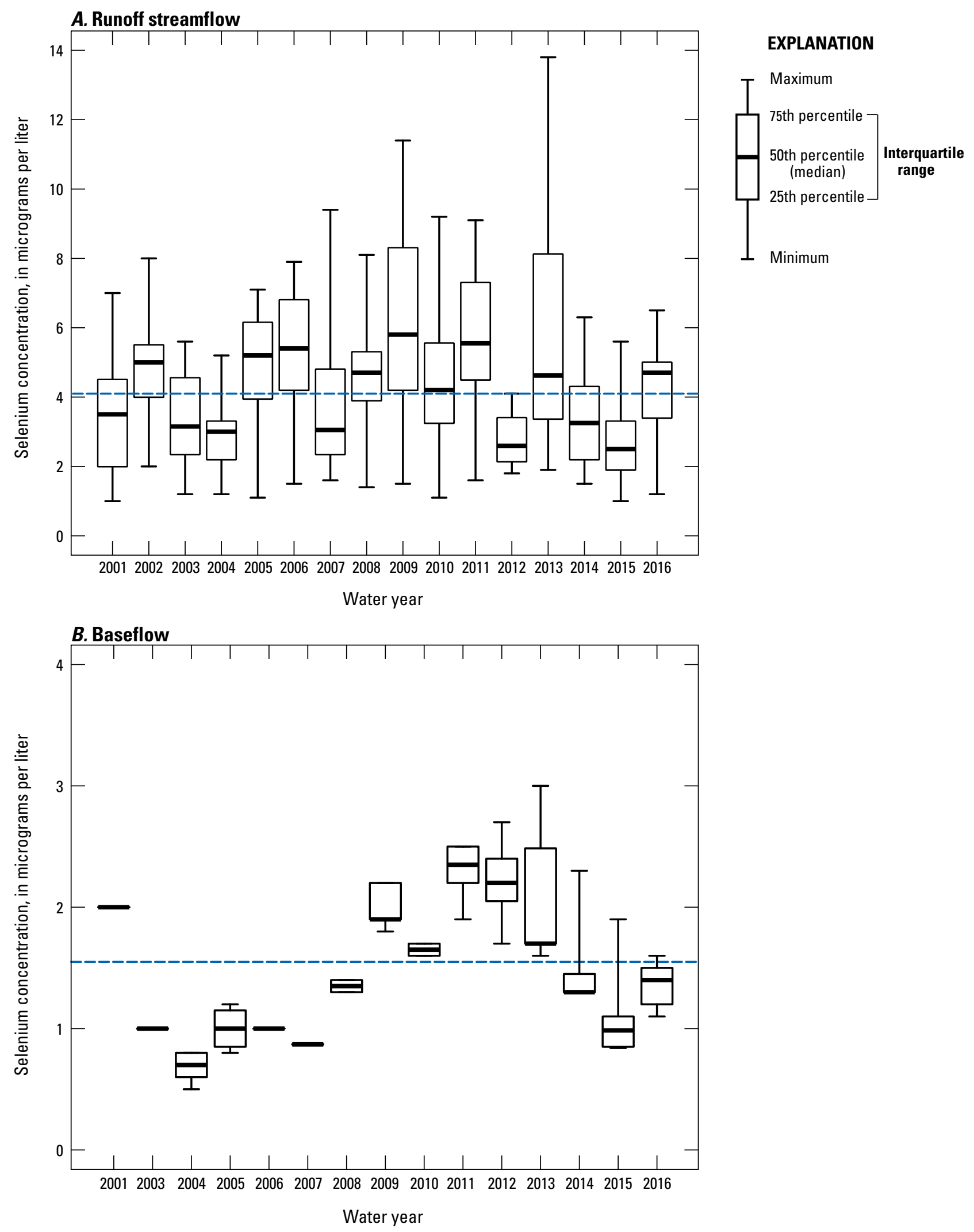

Figure 5. Selenium concentrations (total and dissolved) during ( $A$ ) April and May (runoff streamflow) and $(B)$ August, September, and October (baseflow) in the Blackfoot River above reservoir near Henry, Idaho (13063000). Box extent represents the interquartile range with the median shown and whiskers representing the range of measured values. Dashed line represents the 2001-16 seasonal median (4.1 micrograms per liter $[\mu \mathrm{g} / \mathrm{L}]$ in $A, 1.5 \mu \mathrm{g} / \mathrm{L}$ in $B$ ). Water year 2002 missing from $(B)$ baseflow data because no data are available. 


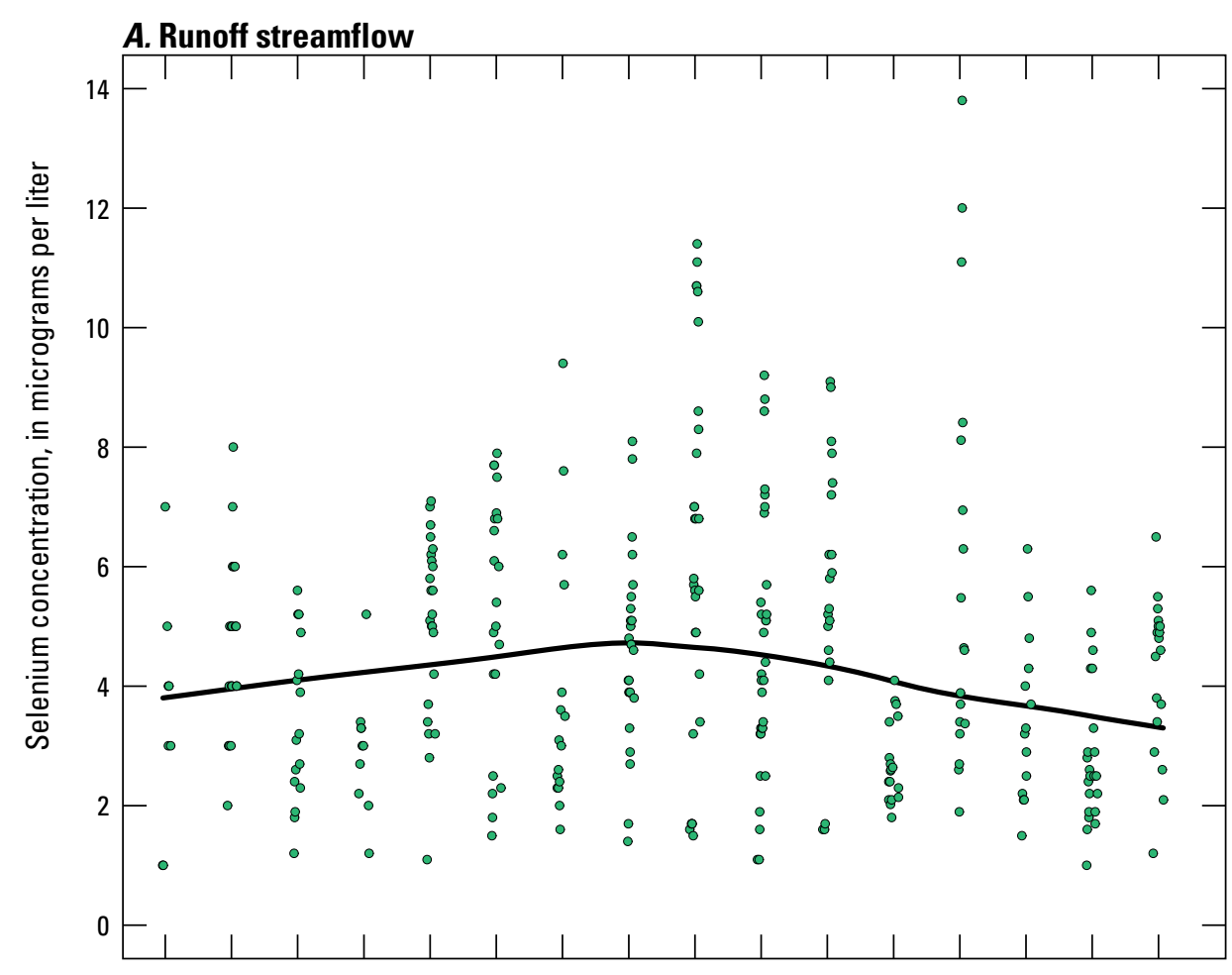

EXPLANATION

Selenium concentration LOESS trend

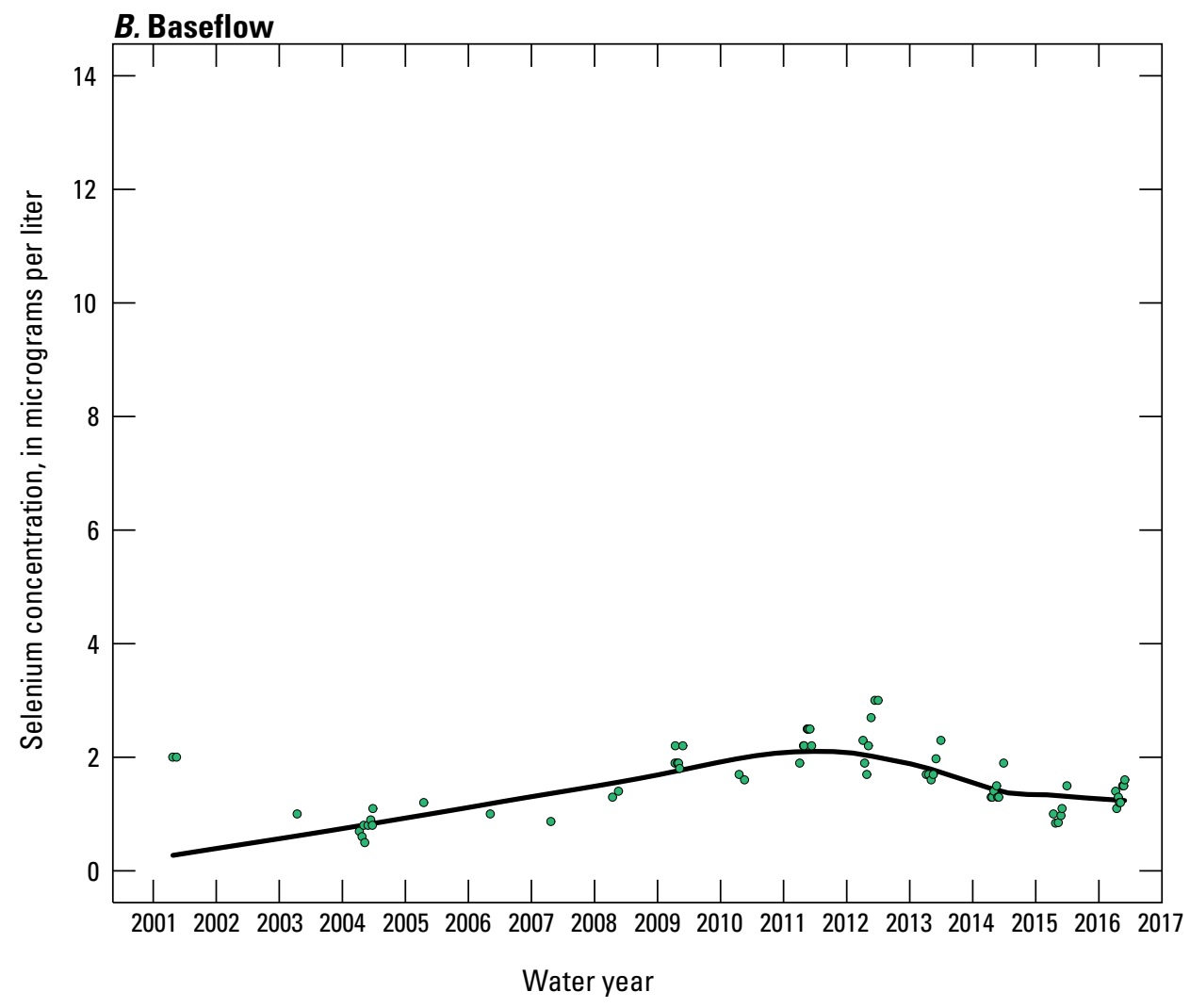

Figure 6. Selenium concentrations (total and dissolved) during (A) April and May (runoff streamflow) and (B) August, September, and October (baseflow) in the Blackfoot River above reservoir near Henry, Idaho (13063000). The LOESS trends are also shown. Water year labels are centered on May 1. 


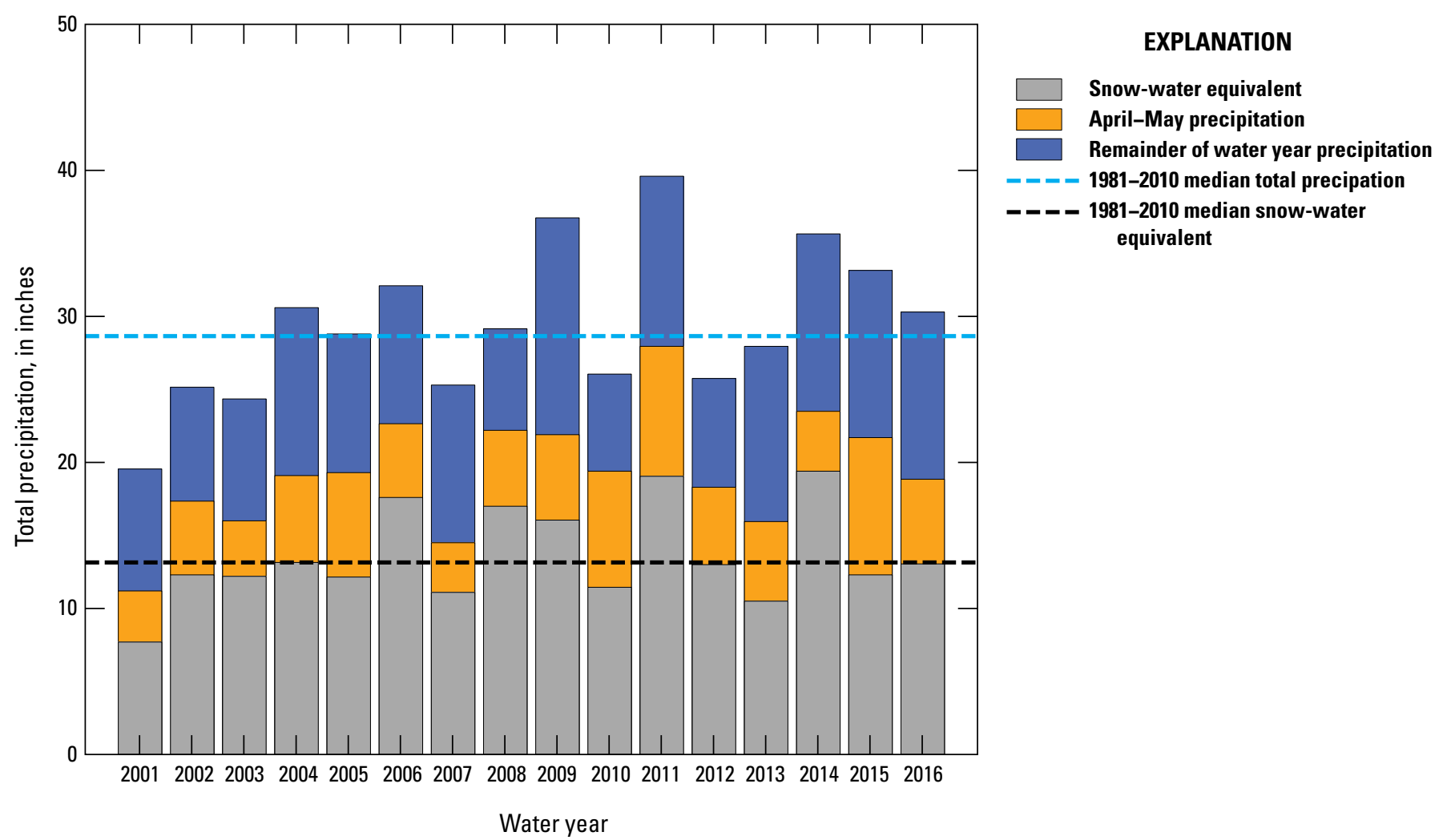

Figure 7. Total water year precipitation in the upper Blackfoot River watershed, southeastern, Idaho, water years 2001-16. Data are averaged from the Slug Creek Divide and Somsen Ranch SNOTEL stations. The height of each water year bar represents the total precipitation (in inches) for the year.

Table 2. Spearman correlations between selenium concentration and streamflow at sites in the upper Blackfoot River watershed, southeastern, Idaho, 2001-16.

[Bold and italic indicate statistical significance at $\mathrm{p}$-value $<0.1$. Abbreviation: $\mathrm{n}$, count of samples used for correlation]

\begin{tabular}{|c|c|c|c|c|}
\hline Site No. & Site name & Spearman's rho & p-value & $\mathbf{n}$ \\
\hline 2 & Blackfoot River at USGS Streamgage & 0.44 & 0.09 & 16 \\
\hline 4 & Blackfoot River at Trail Creek Road & 0.68 & 0.01 & 13 \\
\hline 5 & Trail Creek & 0.05 & 0.88 & 12 \\
\hline 6 & Slug Creek & 0.27 & 0.40 & 12 \\
\hline 9 & Johnson Creek & 0.43 & 0.35 & 7 \\
\hline 10 & Dry Valley Creek & 0.59 & 0.03 & 14 \\
\hline 11 & Goodheart Creek & 0.85 & 0.00 & 13 \\
\hline 12 & Blackfoot River above Narrows & 0.37 & 0.16 & 16 \\
\hline 13 & Angus Creek & -0.31 & 0.26 & 15 \\
\hline 18 & East Mill Creek & 0.69 & 0.01 & 15 \\
\hline 19 & Diamond Creek above confluence with Lanes Creek & 0.35 & 0.50 & 6 \\
\hline 20 & Lanes Creek above confluence with Diamond Creek & 0.53 & 0.06 & 13 \\
\hline 21 & Sheep Creek & 0.75 & 0.01 & 12 \\
\hline 13063000 & USGS station 13063000 & 0.61 & 0.00 & 500 \\
\hline
\end{tabular}



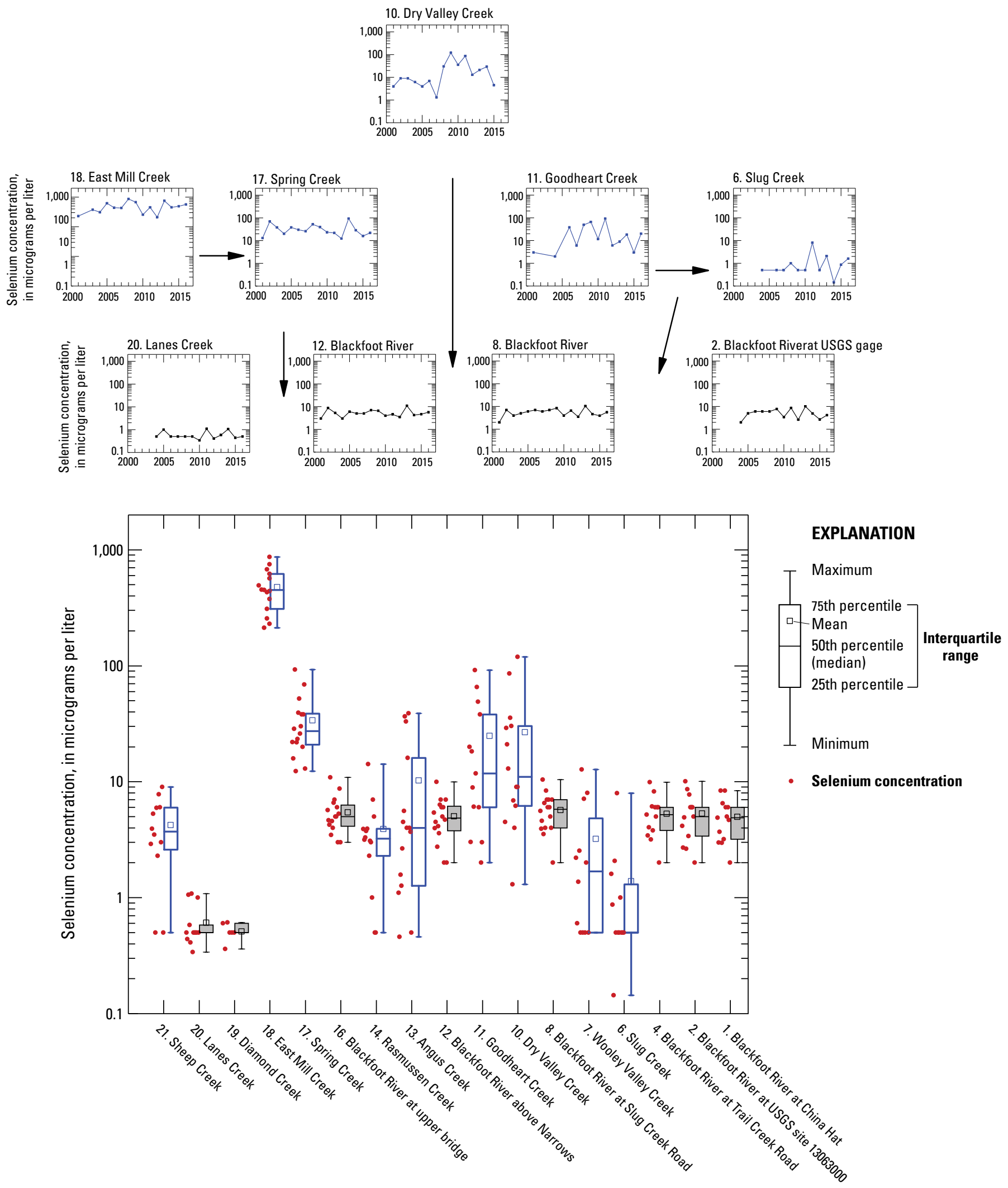

Figure 8. Selenium concentrations in Blackfoot River mainstem (grey-shaded boxes and black line graphs) and tributaries (blue boxes and blue line graphs) from Idaho Department of Environmental Quality annual spring runoff sampling (2001-16). Box extent represents the interquartile range with the median shown and whiskers representing the range of measured values; individual sample concentrations are shown as red dots. Censored data are displayed at the non-detect value. Arrows depict tributary streamflow into other tributaries or into the mainstem Blackfoot River. Mainstem and tributary site numbers (as shown in table 2 and figures 1 and 2) are labeled. 
However, several sites on creeks with upstream mining disturbance do not show a significant correlation between selenium concentration and streamflow; these include sites on Spring Creek, Angus Creek and Slug Creek (table 2). Each of these creeks is affected by conditions that may confound simple correlation between selenium concentration and streamflow. For example, Spring Creek is largely sourced from by alluvial groundwater; mining-impacted Goodheart Creek only connects to Slug Creek in some years; and the sampling location on Angus Creek shifted from an upstream to a downstream location after 2010. Nonetheless, the correlation between selenium concentration and streamflow in most of the mining-affected tributaries in the upper Blackfoot River watershed suggests that the amount of water moving through the mining-affected landscape strongly affects the annual variation in instream selenium concentrations.

The anomalously high selenium concentrations in both the USGS and IDEQ samples collected during May 2013 were consistent with independent data collected by AECOM Technical Services, Inc. (2015a, 2015b) and Arcadis U.S., Inc. (2016) from synoptic sampling of the East Mill Creek- Spring Creek-Blackfoot River area (table 3), which receives drainage from the Maybe Canyon Mine North (fig. 2). Selenium concentrations measured near the headwaters of East Mill Creek were not markedly different in 2013 as compared to 2014 through 2016, with concentrations of about 2,200 to $2,600 \mu \mathrm{g} / \mathrm{L}$. Similarly, selenium loads in the headwaters of East Mill Creek in 2013 were not unusually high (table 3). However, 2013 selenium concentrations in lower Spring Creek and the Blackfoot River were among the highest measured at those sites: 120 and $15 \mu \mathrm{g} / \mathrm{L}$, respectively (table 3 ). These independent results support the conclusion that the East Mill Creek drainage was the source of the high 2013 concentrations and loads in the Blackfoot River, although the specific hydrologic connection is unclear.

Evaluating the accumulation of streamflow and selenium load in the Blackfoot River and tributaries provided another means to understand this system. The Blackfoot River generally accrued groundwater discharge (gaining stream) between the headwaters and the downstream site at USGS station 13063000 (site 2; fig. 9). In most years, tributary inflows cannot account for the gains in streamflow in the Blackfoot River, indicating that groundwater inflows contributed to total streamflow. In most years, substantive nontributary (inferred groundwater) flows were gained between sites 16 and 12 (Blackfoot River at upper bridge and Blackfoot River above Narrows), and between sites 12 and 8 (Blackfoot River above Narrows and Blackfoot River at Slug Creek Road; fig. 2). However, in 2013 the Blackfoot River gained less streamflow between sites 16 and 12 than it gained from Angus Creek (site 13), indicating a streamflow loss in this reach (fig. 9).
The selenium load accumulations in the Blackfoot River varied from year to year (fig. 9). In some years, the selenium load in the mainstem was less than the cumulative tributary load (for example, 2013). In other years, the selenium load in the mainstem was higher than the cumulative tributary load (for example, 2012, 2015 and 2016) or the load in the mainstem showed unaccounted gains larger than the tributary loads in some reaches, and unaccounted losses in other reaches (for example, 2007, 2009, 2011, and 2014; fig. 9). Nonetheless, several general consistencies are apparent. First, East Mill Creek (site 17) generally accounted for the largest proportion of the total Blackfoot River selenium load (Mebane and others, 2015). Second, unaccounted (non-tributary) selenium loads frequently, but not always, occurred between the headwater sites (Diamond and Lanes Creeks, sites 19 and 20) and Blackfoot River at the upper bridge (site 16), and between Blackfoot River at Narrows (site 12) and Blackfoot River at Slug Creek Road (site 8; fig. 9). Mebane and others (2015) noted the unaccounted load increase between sites 16 and 8; this observation, paired with the wide range of selenium concentrations measured in Dry Valley Creek, led to the Dry Valley reach seepage study.

\section{Dry Valley Reach Seepage Study}

During the Dry Valley reach seepage study in June 2016, streamflow decreased slightly over the 3 days of study, but remained relatively stable during each set of synoptic measurements. On each day, streamflow increased from the upstream-most site (T1) to the downstream-most site (T3) by between 7.4 and $9.0 \mathrm{ft}^{3} / \mathrm{s}$ (fig. 10; table 4 ) and the sum of the tributary inflows (Dry Valley Creek and historical Dry Valley Creek) ranged from 1.3 to $1.4 \mathrm{ft}^{3} / \mathrm{s}$. Therefore, the average net unaccounted streamflow increase (that is, the inferred groundwater) in the Blackfoot River from T1 to T3 ranged from $6.0 \pm 3.0$ to $7.7 \pm 3.1 \mathrm{ft}^{3} / \mathrm{s}$, where the plus or minus streamflow represents the propagated measurement uncertainty through the entire reach.

Based on the streamflow measurements at the mainstem sites, most of the streamflow was gained between T2 and T2.5. The reach between T2.5 and T3 showed a slight streamflow loss (about $2 \mathrm{ft}^{3} / \mathrm{s}$ ) but this amount of loss is within the propagated measurement uncertainty (about $\pm 3 \mathrm{ft}^{3} / \mathrm{s}$ ) and therefore is considered neither a net gain nor loss (table 4).

Selenium concentrations in the Blackfoot River also increased consistently from $\mathrm{T} 1$ to $\mathrm{T} 3$ on each of the three days, with an average of $1.52 \mu \mathrm{g} / \mathrm{L}$ at $\mathrm{T} 1$ to $1.89 \mu \mathrm{g} / \mathrm{L}$ at T3 (table 4). The selenium concentration in Dry Valley Creek averaged $1.43 \mu \mathrm{g} / \mathrm{L}$, and the single sample collected from historical Dry Valley Creek was $0.28 \mu \mathrm{g} / \mathrm{L}$. Although the upstream to downstream increase in selenium concentration 
Table 3. Selenium concentrations and loads from synoptic surveys of East Mill Creek, Spring Creek, and the Blackfoot River, 2013-16.

[Data sources: AECOM Technical Services, Inc. (2015a, 2015b) and Arcadis (2016). East Mill Creek (middle reach): Similar location to Idaho Department of Environmental Quality (IDEQ) site 18 (East Mill Creek). Spring Creek, near the mouth: Similar location to IDEQ site 17 (Spring Creek). Abbreviations: $\mu \mathrm{g} / \mathrm{L}$, microgram per liter; $\mathrm{kg} / \mathrm{d}$, kilogram per day; <, less than]

\begin{tabular}{|c|c|c|c|c|c|c|}
\hline \multicolumn{6}{|c|}{ Selenium concentrations ( $\mu \mathrm{g} / \mathrm{L}$ ) } & \\
\hline $\begin{array}{c}\text { Synoptic } \\
\text { survey date }\end{array}$ & $\begin{array}{l}\text { East Mill Creek } \\
\text { (headwaters) }\end{array}$ & $\begin{array}{c}\text { East Mill Creek } \\
\text { (middle reach) }\end{array}$ & $\begin{array}{l}\text { Spring Creek, } \\
\text { near the mouth }\end{array}$ & $\begin{array}{l}\text { Blackfoot River } \\
\text { downstream of } \\
\text { Spring Creek }\end{array}$ & $\begin{array}{c}\text { Blackfoot River } \\
\text { upstream of Spring } \\
\text { Creek }\end{array}$ & \\
\hline \multicolumn{6}{|c|}{ High streamflow samplings } & \\
\hline $05-10-16$ & 2,600 & 402 & 18 & 11.1 & 0.40 & \\
\hline $04-28-15$ & 2,500 & 390 & 23 & ${ }^{1} 57.0$ & 0.55 & \\
\hline 05-14-13 & 2,200 & 760 & 120 & 15.0 & 0.51 & \\
\hline \multicolumn{6}{|c|}{ Low streamflow samplings } & \\
\hline $09-22-16$ & 2,200 & 32 & 4.0 & 1.3 & $<0.2$ & \\
\hline $09-28-15$ & 2,400 & 42 & 3.7 & ${ }^{1} 15.5$ & $<0.2$ & \\
\hline 09-24-14 & 1,900 & 33 & 2.6 & 18.6 & $<0.25$ & \\
\hline $09-29-13$ & 1,800 & 36 & 5.1 & 1.8 & $<0.12$ & \\
\hline $05-10-16$ & 6.35 & 3.54 & 1.69 & 6.1 & 0.39 & 5.71 \\
\hline $04-28-15$ & 3.67 & 2.96 & 1.11 & ${ }^{1} 19.4$ & 0.23 & 19.15 \\
\hline $05-09-14$ & 6.06 & 4.89 & 2.12 & 2.3 & 0.30 & 2.02 \\
\hline $05-14-13$ & 4.20 & 8.37 & 5.87 & 4.4 & 0.29 & 4.07 \\
\hline $09-22-16$ & 0.01 & 0.09 & 0.13 & 0.18 & 0.03 & 0.15 \\
\hline $09-28-15$ & 0.05 & 0.16 & 0.15 & ${ }^{1} 2.20$ & 0.05 & 2.15 \\
\hline $09-24-14$ & 0.02 & 0.11 & 0.06 & ${ }^{1} 0.93$ & 0.02 & 0.90 \\
\hline 09-29-13 & 0.10 & 0.11 & 0.10 & 0.15 & 0.02 & 0.14 \\
\hline
\end{tabular}

\footnotetext{
${ }^{1}$ Selenium concentrations are considered high biased because samples were collected immediately downstream of a contaminated tributary confluence (IDEQ site 17a), which has selenium concentrations ranging from at least 19 to $307 \mu \mathrm{g} / \mathrm{L}$; the samples are therefore not directly comparable with the fully mixed, width and depth integrated samples collected by IDEQ at site 16 .
}

between $\mathrm{T} 1$ and $\mathrm{T} 3$ was relatively small, it was consistent on all three days. Paired with the reach increase in streamflow, the selenium load increased from an average of $0.372 \mathrm{~kg} / \mathrm{d}$ at T1 to $0.501 \mathrm{~kg} / \mathrm{d}$ at T3 (table 4 and fig. 10). No measurable selenium load was contributed by historical Dry Valley Creek and only $0.005 \mathrm{~kg} / \mathrm{d}$, on average, was contributed from Dry Valley Creek. Thus, on average, about $0.125 \mathrm{~kg} / \mathrm{d}$ of unaccounted selenium accumulated in the Blackfoot River between $\mathrm{T} 1$ and $\mathrm{T} 3$.

Assuming that all the unaccounted streamflow and selenium load between T1 and T3 is derived from groundwater (eqn. 3, in section, "Statistical Interpretations") can be used to estimate the average groundwater concentration of selenium.
Assuming an average unaccounted groundwater inflow of $6.8 \mathrm{ft}^{3} / \mathrm{s}$ (table 4 ), the average selenium concentration in groundwater contributed to the Blackfoot River between $\mathrm{T} 1$ and $\mathrm{T} 3$ would be $7.50 \mu \mathrm{g} / \mathrm{L}$. However, this calculation is sensitive to streamflow measurement uncertainty; if the measurement uncertainty is used to bound upper and lower rates of groundwater entering the Blackfoot River at 10.0 and $3.6 \mathrm{ft}^{3} / \mathrm{s}$, respectively, the average groundwater selenium concentration could range from $5.12 \mu \mathrm{g} / \mathrm{L}$ to $14.0 \mu \mathrm{g} / \mathrm{L}$. This also assumes that all of the unaccounted streamflow and selenium load is derived from groundwater; alternate sources are discussed in later sections of this report. 
$\boldsymbol{A}$

\section{Cumulative streamflow accumulations}
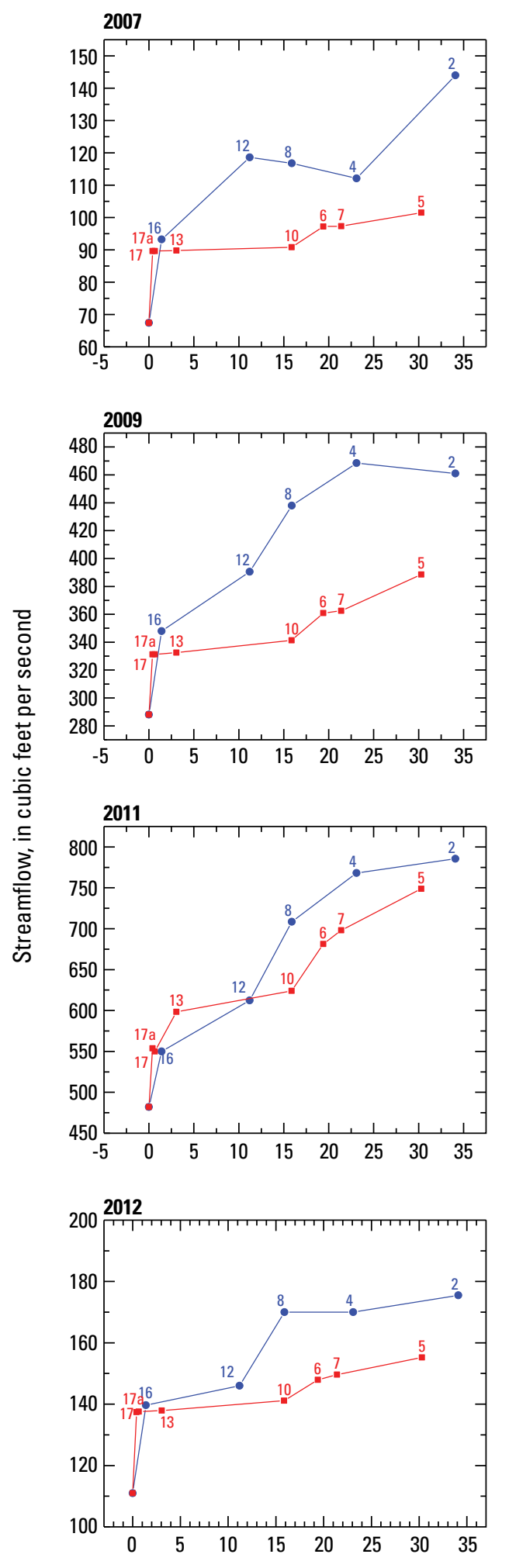

\section{Cumulative selenium load accumulations}
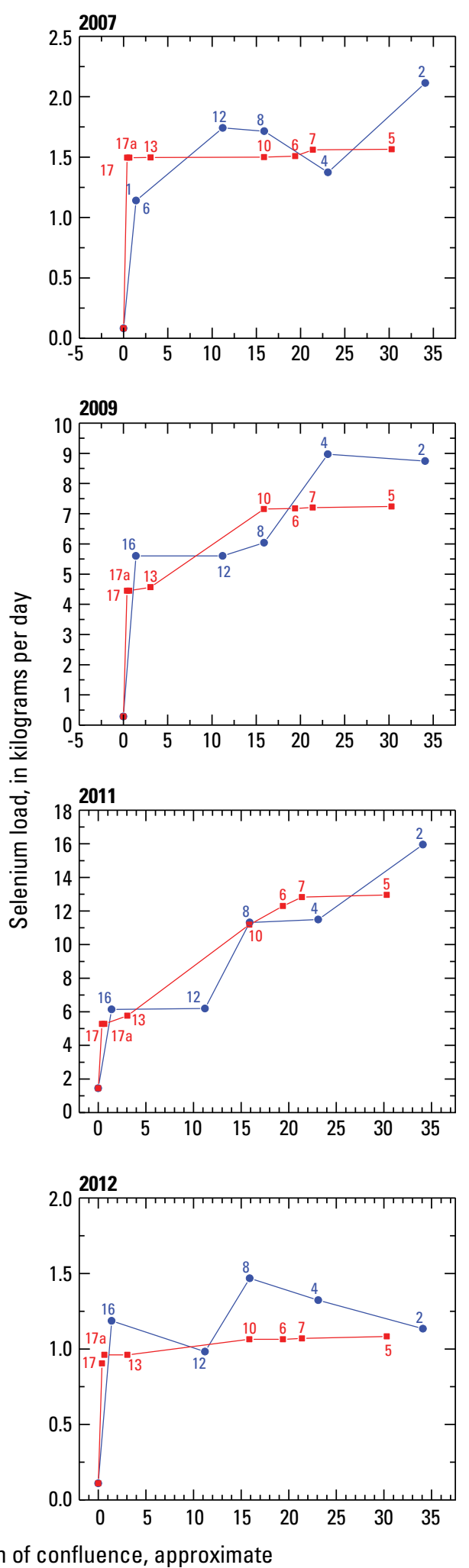

Figure 9. Cumulative streamflow and selenium load accumulation in the Blackfoot River and tributaries, southeastern Idaho. Measured by the Idaho Department of Environmental Quality during spring runoff in 2007, 2009, and 2011-16. Mainstem and tributary site numbers (as shown in table 2 and figures 1 and 2) are labeled. Note the vertical axis varies between plots. Distance 0 represents the confluence of Diamond and Lanes Creek, which marks the start of the Blackfoot River. 
B

Cumulative streamflow accumulations
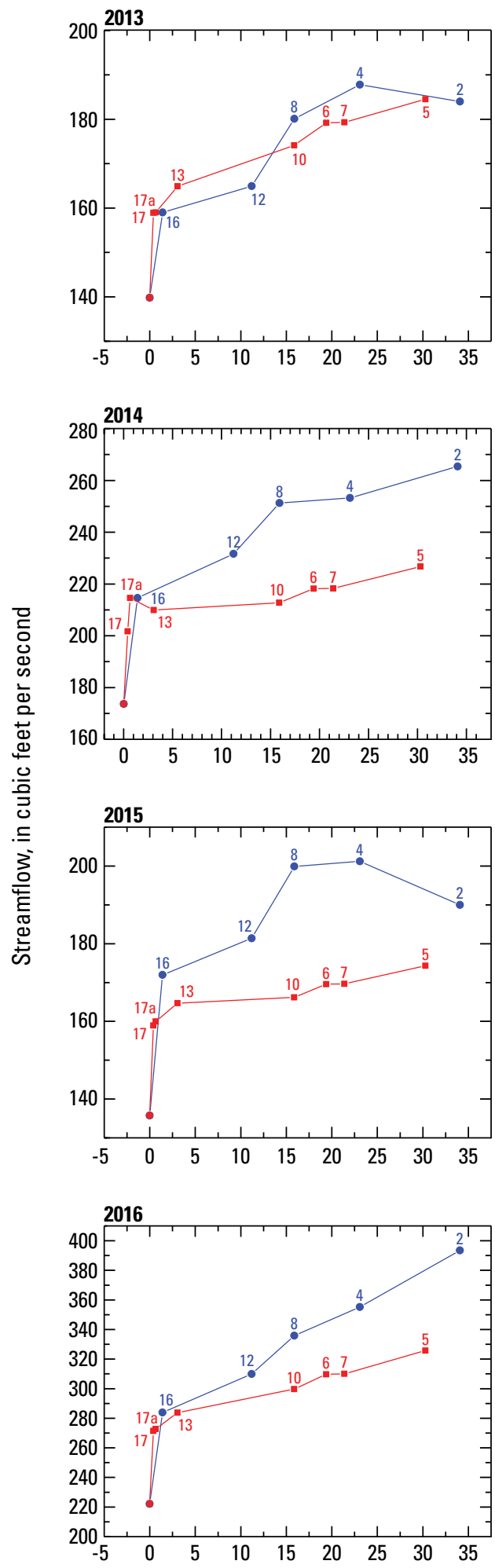

River miles downstream of confluence, approximate
Cumulative selenium load accumulations
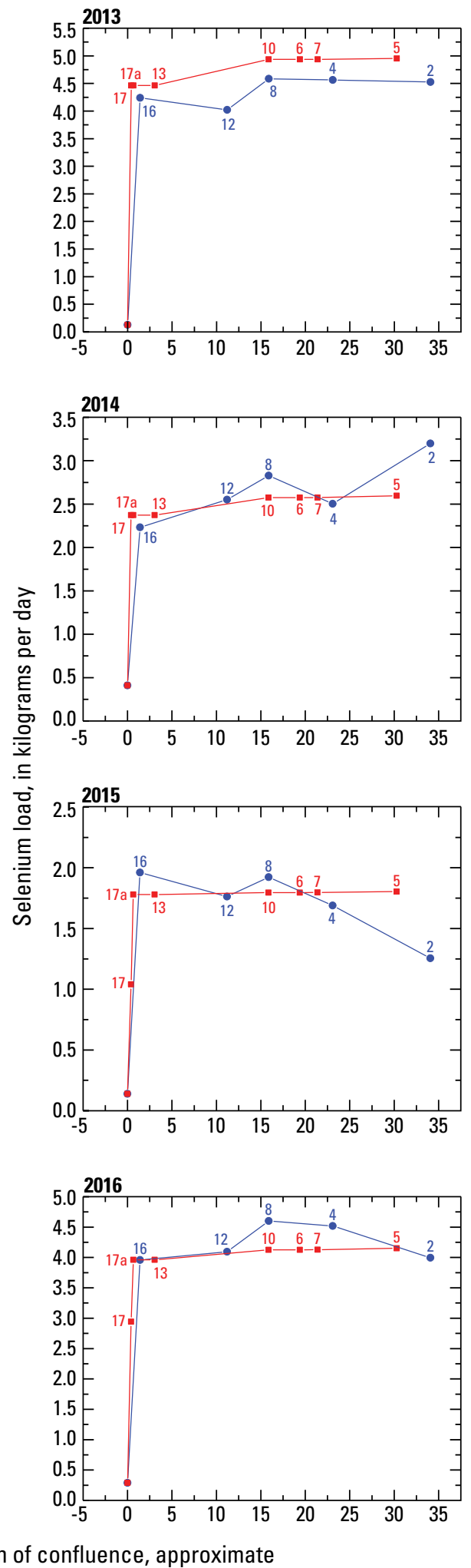

Figure 9.-Continued 


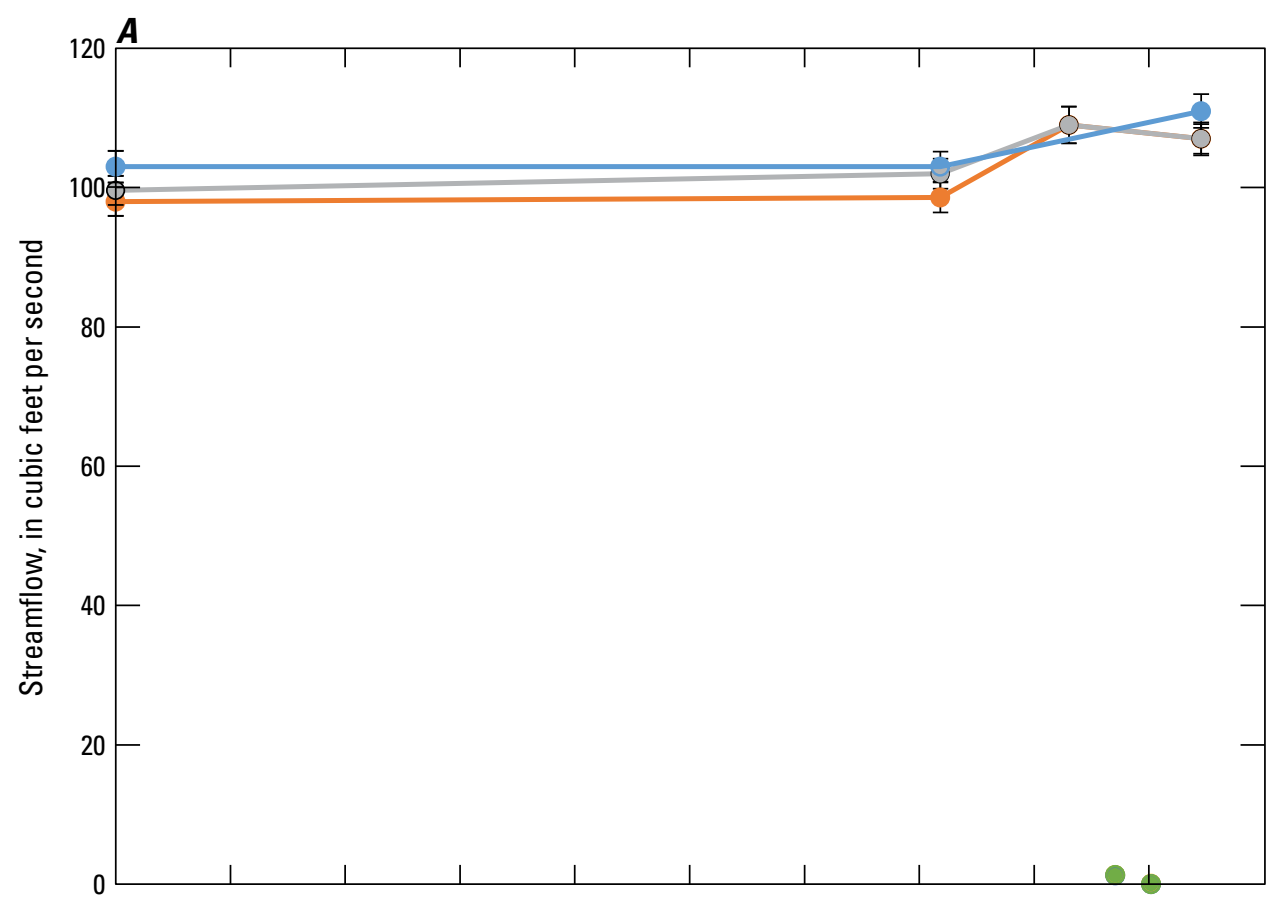

\section{EXPLANATION}

$\rightarrow$ Day 1 main stem

$\rightarrow$ Day 2 main stem

$\rightarrow$ Day 3 main stem

- Day 1 tributaries

- Day 2 tributaries

- Day 3 tributaries

\$ Streamflow measurement uncertainty

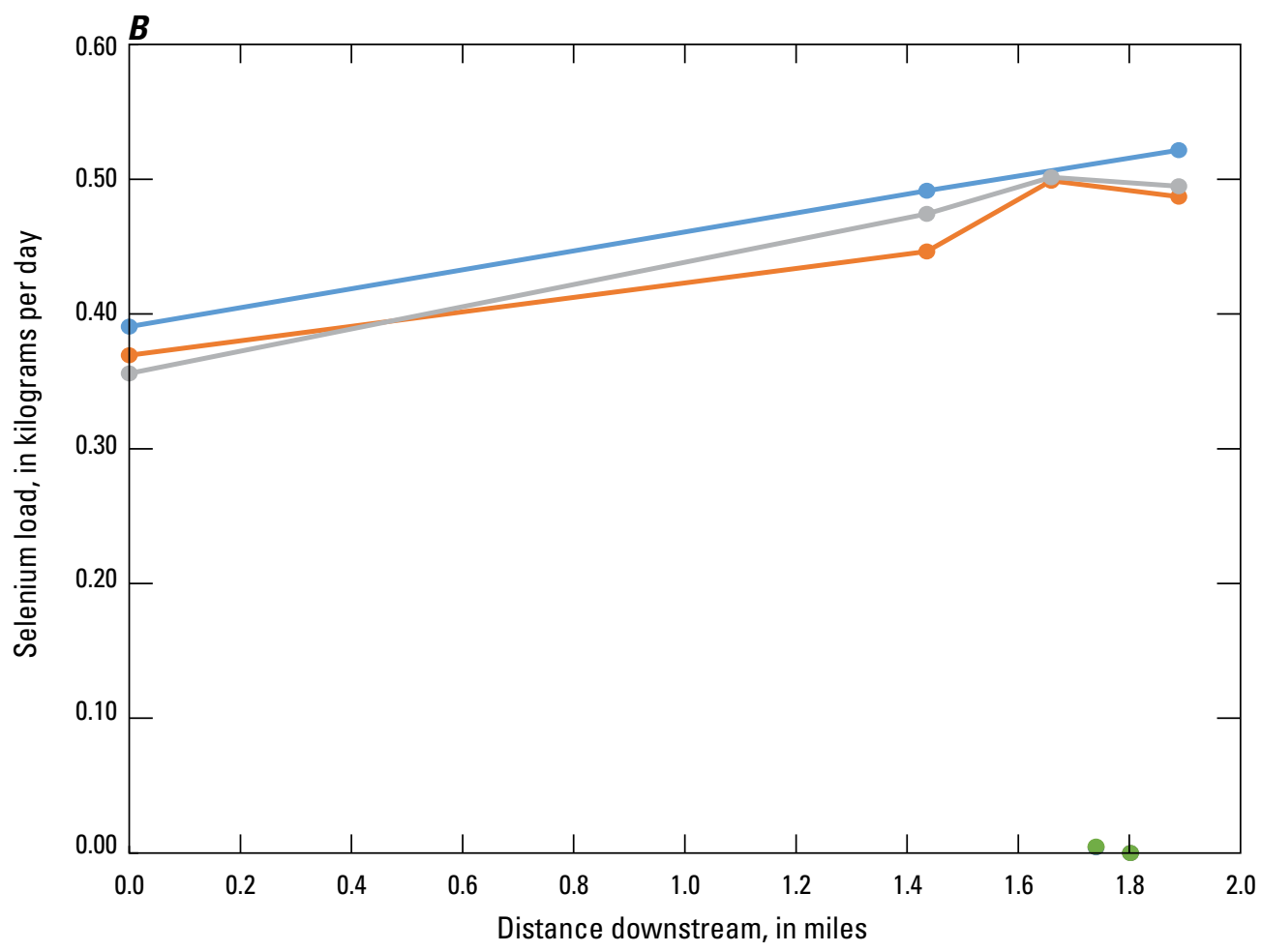

Figure 10. Seepage study streamflow $(A)$ and selenium load $(B)$ accumulation in the Blackfoot River and tributaries, upper Blackfoot River watershed, southeastern, Idaho. Where Day 1 and Day 2 tributary symbols are not visible, values were equal to, and obscured by, Day 3 values. Sample sites are shown in figure 1. Error bars in A represent streamflow measurement uncertainty. 
Table 4. Streamflow and selenium concentrations (dissolved) and loads from the Dry Valley reach seepage study, upper Blackfoot River watershed, southeastern, Idaho.

[Abbreviations: mi, mile; $\mathrm{ft}^{3} / \mathrm{s}$, cubic foot per second; $\mathrm{kg} / \mathrm{d}$, kilogram per day; $\mu \mathrm{g} / \mathrm{L}$, microgram per liter; -, no data]

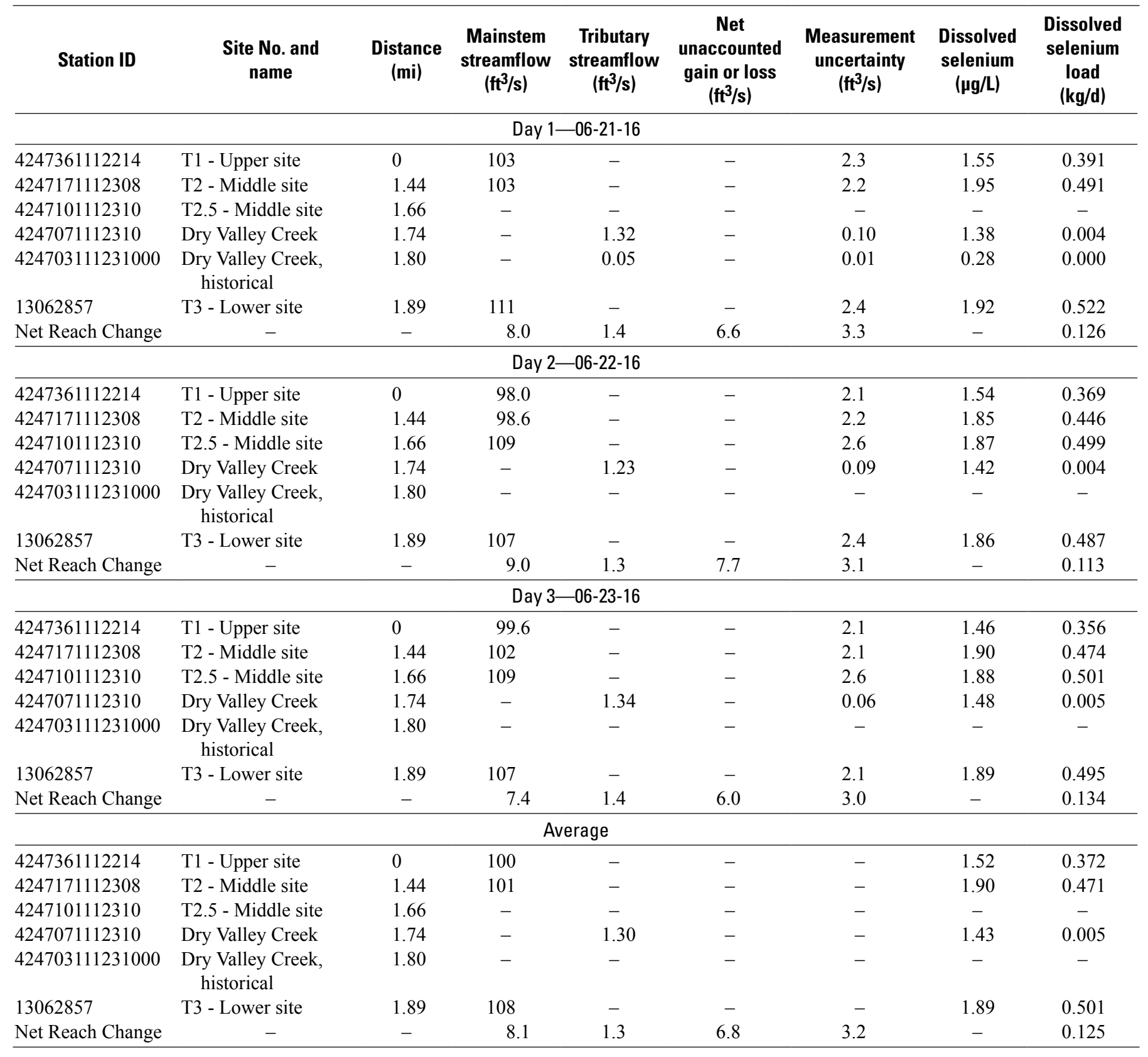




\section{Discussion}

\section{Selenium During Runoff}

The relations between streamflow, snowpack, and selenium concentration in the mainstem Blackfoot River and mining-affected tributaries leads to a conceptual understanding of selenium transport in the watershed. The magnitude of selenium concentration during runoff is related to the streamflow magnitude (fig. 3), and in this mountainous region the size and shape of the streamflow hydrograph is driven by the depth of snowpack and the timing of runoff. A series of high snowpack years occurred in 2006, 2008, 2009, and 2011 (fig. 7). These years align with a period of higher than median selenium concentrations during runoff flows (fig. 5), and the lower snowpack years prior to 2006 and following 2011 coincide with the lower than median selenium concentrations in runoff flows (fig. 5). Conceptually, this suggests that the amount of snowmelt moving through the landscape in a given year influences the concentration of selenium in the Blackfoot River and tributaries.

Contrary to fluvial systems in which sediment-bound contaminants are primarily transported during sediment mobilization near peak snowmelt runoff, selenium transport in the Blackfoot River is dominated by dissolved rather than particulate selenium (Presser and others, 2004b) and peak concentrations lag behind peak streamflow (fig. 4). As posited by Mebane and others (2015), this lag could arise as snowmelt percolates through cross-valley fill mine dumps, effectively taking a more tortuous path to streams as compared to runoff directly into streams, but still passing through the dumps relatively efficiently (Sidle and others, 1994; Amacher and others, 1995; Mars and Crowley, 2003). Alternately, if East Mill Creek largely drives selenium concentrations in the Blackfoot River (fig. 8), then annual snowmelt timing on the higher elevation and north-facing Maybe Canyon Mine North dump (which largely sources East Mill Creek) may be an important contributor to the observed selenium lag.

The hypothesis that snowmelt percolation through waste rock controls selenium transport is also geochemically plausible. High selenium concentrations measured during runoff conditions are similar to the "first flush" effect seen in other mining affected areas where the first high streamflow following a dry period causes the dissolution of soluble metal salts and subsequent high metal concentrations in streams (Nordstrom, 2009). Selenium in the Meade Peak member occurs primarily in association with sulfide minerals (such as, pyrite and sphalerite) and in elemental form (Grauch and others, 2004; Perkins and Foster, 2004; Stillings and Amacher, 2010) but readily oxidizes to more mobile forms when exposed to air and water (Herring, 2004; Knudsen and Gunter, 2004; Stillings and Amacher, 2010). Although selenium salts have not been directly identified, zinc sulfate salts have been measured and observed to occur with selenium (of indeterminate form) on newly mined rock faces (Grauch and others, 2004), and Perkins and Foster (2004) detected selenate associated with acid-soluble oxyhydroxides in weathered Meade Peak rocks.

With respect to selenium mobilization, field data from a Wooley Valley waste rock dump paired with laboratory data showed that selenium concentrations following initial wetting were highest and subsequently decreased to a lower, steady-state concentration. These kinetics data indicate that water passing through waste rock dissolves and mobilizes readily available forms of selenium (selenate), and then slowly oxidizes less soluble selenium (elemental or sulfide mineral bound selenium) over time (Stillings and Amacher, 2010). In the absence of enough water to move the slowly oxidizing selenium, this oxidized selenium may build up over dry periods and then be mobilized in high concentrations with the next rain or snowmelt event. Thus, the high concentrations of selenium measured in the Blackfoot River and tributaries following peak streamflows is geochemically consistent with the mobilization of soluble selenium via snowmelt moving through waste rock.

High snowpack years could increase selenium transport to the hydrologic system in several ways. Larger amounts of snowmelt passing through cross-valley fill dumps allows for more water-mineral contact, subsequently mobilizing more available selenium during spring runoff. Additionally, increased and prolonged snowmelt runoff percolating through the dumps could release more of the less soluble selenium in the rocks over time (Stillings and Amacher, 2010). This oxidized selenium may be released later in the season, resulting in higher selenium concentrations during baseflow in the Blackfoot River and tributaries; it may move into shallow alluvial groundwater (Hay and others, 2016); or it may be "primed" to be released during the following spring when the next year's snowmelt percolates through the cross-valley fill dumps (Nordstrom, 2009). Such a priming mechanism is congruent with the relatively high selenium concentrations seen in unremarkable snowmelt years that followed high snowmelt years (for example, 2007 and 2010).

As an aside, the kinetics work completed by Stillings and Amacher (2010), and previously described here, used field data collected in 2002, 2006, and 2008, which were the only years during 2002-08 that the seep at the base of the Wooley Valley waste rock dump flowed enough to collect samples and measure streamflow. Thus, there is evidence that this mechanism of selenium release and transport in the upper Blackfoot River watershed may primarily occur under certain snowpack and precipitation conditions, which may account for some of the variability in year-to-year selenium concentrations in the Blackfoot River and tributaries.

Some of the annual variability of instream selenium concentrations likely results from local variability in snowpack accumulation and snowmelt conditions. Total snow water equivalent is being used here as a coarse indicator of the amount of water moving through the landscape during the runoff period. Although there is a strong correlation between 
snow water equivalent and streamflow, the manner in which runoff occurs and therefore the amount of water moving through the landscape, is likely to be dependent on multiple factors. These factors may include the timing and rate of snowmelt, the spatial distribution of snow on the landscape, the occurrence of rainfall during snowmelt, variations in air temperature, the antecedent soil conditions (including water content and temperature), and the water table of the shallow alluvial groundwater. All of these factors can affect local water movement and likely contribute to some of the variability in the selenium concentrations in both the mainstem Blackfoot River and tributaries.

\section{Selenium During Baseflow}

Whereas median selenium runoff concentrations seemed to peak during 2008 and 2009 and then decrease, the LOESS trend for higher concentrations during baseflow lagged with a peak in 2013 before decreasing (fig. 6). Because baseflows in the Blackfoot River are primarily sustained by groundwater inflow, the increase in baseflow selenium concentrations until 2013 could indicate increasing concentrations of selenium in groundwater. When selenium is weathered in waste rock dumps, it can be mobilized and percolate into groundwater where it may remain in solution at elevated concentrations under high oxygen conditions or be attenuated through microbially mediated reductive precipitation under low oxygen conditions (Hay and others, 2016). Under oxygenated conditions, shallow alluvial groundwater with elevated selenium concentrations may discharge to tributaries of the Blackfoot River or into the mainstem itself. Unfortunately, there is limited information available on the shape of the alluvial water table and thus the direction of groundwater movement on a watershed-wide scale.

However, selenium moves through the environment in a variety of complex ways that could also affect instream baseflow concentrations. For example, selenium is readily taken up by phytoplankton and bacteria, which in turn may pass selenium up the food chain or release selenium through senescence of aquatic plants (Chapman and others, 2009). Senescence might be a reasonable explanation for small increases measured during late autumn and early winter (November-December) but seems less plausible during August, September, and October when plant growth is likely still occurring. For instance, in a low-gradient, groundwaterfed eastern Idaho River, aquatic plant beds reach their annual biomass maxima in September, and their annual biomass minima in February (Angradi, 1991).

Similarly, stream sediments and exchange of water through the hyporheic zone can also serve as either sources or sinks of selenium. Oram and others (2010) showed that anoxic conditions deeper within the hyporheic zone promoted reprecipitation and sequestration of selenium from surface water in East Mill Creek. Alternately, Oram and others (2008) proposed that the oxygenated, approximately neutral $\mathrm{pH}$
Blackfoot River may dissolve selenium-substituted pyrite in sediments near the water-sediment interface. Such sediments could be a long-term source of dissolved selenium when river concentrations of selenium remain less than $1.6 \mu \mathrm{g} / \mathrm{L}$ (Oram and others, 2010). It is possible that increased hyporheic exchange of water and selenium associated with high baseflows in the middle of the study period promoted increased dissolution of selenium. However, the increased baseflow selenium concentrations measured from 2009 to 2013 averaged about $2 \mu \mathrm{g} / \mathrm{L}$ (fig. $5 B$ ) which suggests selenium loading beyond pyrite dissolution occurred during this time. Thus, baseflow selenium concentrations may be controlled by alluvial groundwater selenium concentrations and discharge to the Blackfoot River, but a more comprehensive understanding of the connectivity and selenium concentrations in the alluvial aquifer would aid interpretation.

\section{Selenium in the Blackfoot River Near Dry Valley}

Loading analysis of the mainstem Blackfoot River and tributaries from 2001 to 2016 showed multiple years with unaccounted mainstem loading of selenium (in excess of the tributary contributions) in the vicinity of Spring Creek and Dry Valley. This unaccounted loading motivated the limited scope evaluation of seepage in the Dry Valley. During the June 2016 study, small but consistent unaccounted increases in streamflow and selenium load were measured in the Dry Valley reach of the Blackfoot River (fig. 10).

These unaccounted flows and load may be derived from discharge of alluvial groundwater from the northern or southern sides of the river. Selenium loading to alluvial groundwater is known to occur within Dry Valley (Hay and others, 2016; Whetstone Associates, 2017), located south of the river. Additionally, a small seep on the northern side of the river near T2 was identified during the study. The selenium concentration in the seep $(2.44 \mu \mathrm{g} / \mathrm{L})$ was somewhat higher than the concentrations in Dry Valley Creek or the Blackfoot River, although the estimated discharge from the seep was only about $0.03 \mathrm{ft}^{3} / \mathrm{s}$. Therefore, although the seep itself does not contribute appreciably to the selenium load in the Blackfoot River, it may be indicative of selenium concentrations in alluvial groundwater north of the river.

Alternately, the variations in selenium concentration in the Blackfoot River through the Dry Valley reach may be unrelated to variations in streamflow. As previously discussed, selenium can be taken up and released by phytoplankton and bacteria and can be released or sequestered by sediment in the hyporheic zone. However, increases in streamflow and selenium loading have been measured during multiple runoff events (fig. 9). Increases in streamflow and selenium loading $(0.125 \mathrm{~kg} / \mathrm{d})$ to the Dry Valley reach during the inferred groundwater study were lower than the increases observed during the 2016 runoff streamflow and load study $(0.35 \mathrm{~kg} / \mathrm{d})$, and substantially lower than the average runoff selenium loading $(2.17 \mathrm{~kg} / \mathrm{d})$ to the reach estimated from multiple years 
of IDEQ sampling. This suggests that most of the selenium loading to the Dry Valley reach of the Blackfoot River probably occurs during or near runoff.

From a mechanistic perspective, the water table in the shallow alluvial aquifer increases in concert with spring snowmelt (Whetstone Associates, 2017), which may result in an increase in the gradient between the shallow groundwater and Blackfoot River. With an increased gradient, water percolating through waste rock in the valleys north and south of the river may be transported more quickly and in greater quantity towards the Blackfoot River. This transport mechanism seems to be a plausible means for loading in the Dry Valley reach during runoff. Nonetheless, an improved understanding of the alluvial aquifer, including extent, hydraulic conductivity, and selenium concentration, in the vicinity of the Dry Valley reach would help in the interpretation of selenium loading to the Blackfoot River.

\section{Future Monitoring Considerations}

Environmental planning, monitoring, modeling, and assessment of phosphate mining in Idaho has long relied upon the former aquatic life criterion of $5 \mu \mathrm{g} / \mathrm{L}$ in water as a performance benchmark. As of March 28, 2018, the Idaho Department of Environmental Quality (2017) set the sitespecific selenium criterion for the upper Blackfoot River watershed to a scheme based upon fish tissue concentrations and water column values (section 287.01; reproduced in table 5). This recent adoption of revised State of Idaho selenium criteria replaced a fixed water concentration-based criterion with a comparatively complex framework of fish tissue and water selenium criteria and introduces additional monitoring considerations.
The criterion is defined in a four-part priority scheme where, if sufficient data are available, the egg-ovary concentrations supersede all other measures, and the wholebody or muscle fish tissue supersede the water column values. Whole-body and muscle tissue values have equal priority. For comparison with criterion, tissue samples from at least five fish of the same species are either blended into a composite sample before analysis or averaged from individual analyses. In the absence of steady-state condition fish tissue values, water column values are intended to be the applicable criterion element (Idaho Department of Environmental Quality, 2017, section 287.01). More generally, the Idaho rules specify in section 287 that site-specific water column values are based on dissolved total selenium using either the mechanistic modeling method or the bioaccumulation factor (BAF) method described in the national selenium criteria document (U.S. Environmental Protection Agency, 2016).

To give context to this new criterion, existing resident fish tissue samples for the mainstem upper Blackfoot River that were collected during the period in which the USGS and IDEQ conducted selenium water sampling are compiled in table 6 (Idaho Department of Fish and Game, 2018). The data, which are mostly whole-body tissue samples, show that selenium residues in fish tissue were close to the criterion values for the upper Blackfoot River for most samples and times. Average concentrations in sculpin were slightly higher than in trout or dace, which might indicate the restricted motility of sculpin. However, differences between the averages were not large and the variabilities among samples from the same species were greater than differences between species averages. Across all samplings, cutthroat trout (Oncorhynchus clarkii bouvieri) averaged 11.5 ( \pm standard deviation of 2.8), dace $13.0( \pm 1.8)$, and sculpin $15.9( \pm 5.0), \mathrm{mg} / \mathrm{kg}$ dry weight, respectively (from table 6 ).

Table 5. Site-specific aquatic life criterion values for the upper Blackfoot River watershed, southeastern Idaho.

[From Idaho Department of Environmental Quality (variously dated). Abbreviations: mg, milligram; kg, kilogram; dw, dry weight; $\mu$ g, microgram; L, liter]

\begin{tabular}{|c|c|c|c|c|}
\hline \multicolumn{4}{|c|}{ Chronic } & \multirow{2}{*}{$\begin{array}{c}\text { Short-term, ST } \\
\text { Water column } \\
\text { Dissolved Se, } \mu \mathrm{g} / \mathrm{L}\end{array}$} \\
\hline & Whole body & Muscle (filet) & Dissolved Se, $\mu \mathrm{g} / \mathrm{L}$ & \\
\hline 24.5 & 12.5 & 12.8 & $\mathrm{WQC}=$ Tissue $_{\text {criterion }} / \mathrm{BAF}$ & $\mathrm{ST}=\left(\mathrm{WQC}-\mathrm{C}_{\text {bkgrnd }}\left(1-\mathrm{f}_{\mathrm{int}}\right)\right) / \mathrm{f}_{\mathrm{int}}$ \\
\hline
\end{tabular}

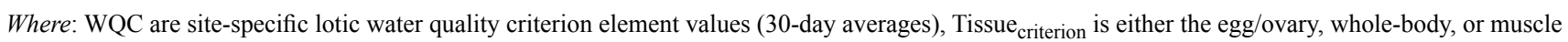
fish tissue criteria elements, BAF is the bioaccumulation factor derived by dividing the site-specific field collected samples of fish tissue (whole-body) by sitespecific field collected samples of water, $\mathrm{C}_{\text {bkgrnd }}$ is the average background dissolved selenium concentration, and $\mathrm{f}_{\text {int }}$ is the fraction of any 30 -day period during which elevated selenium concentrations occur, constrained to be $\geq 0.033$ (one day) 


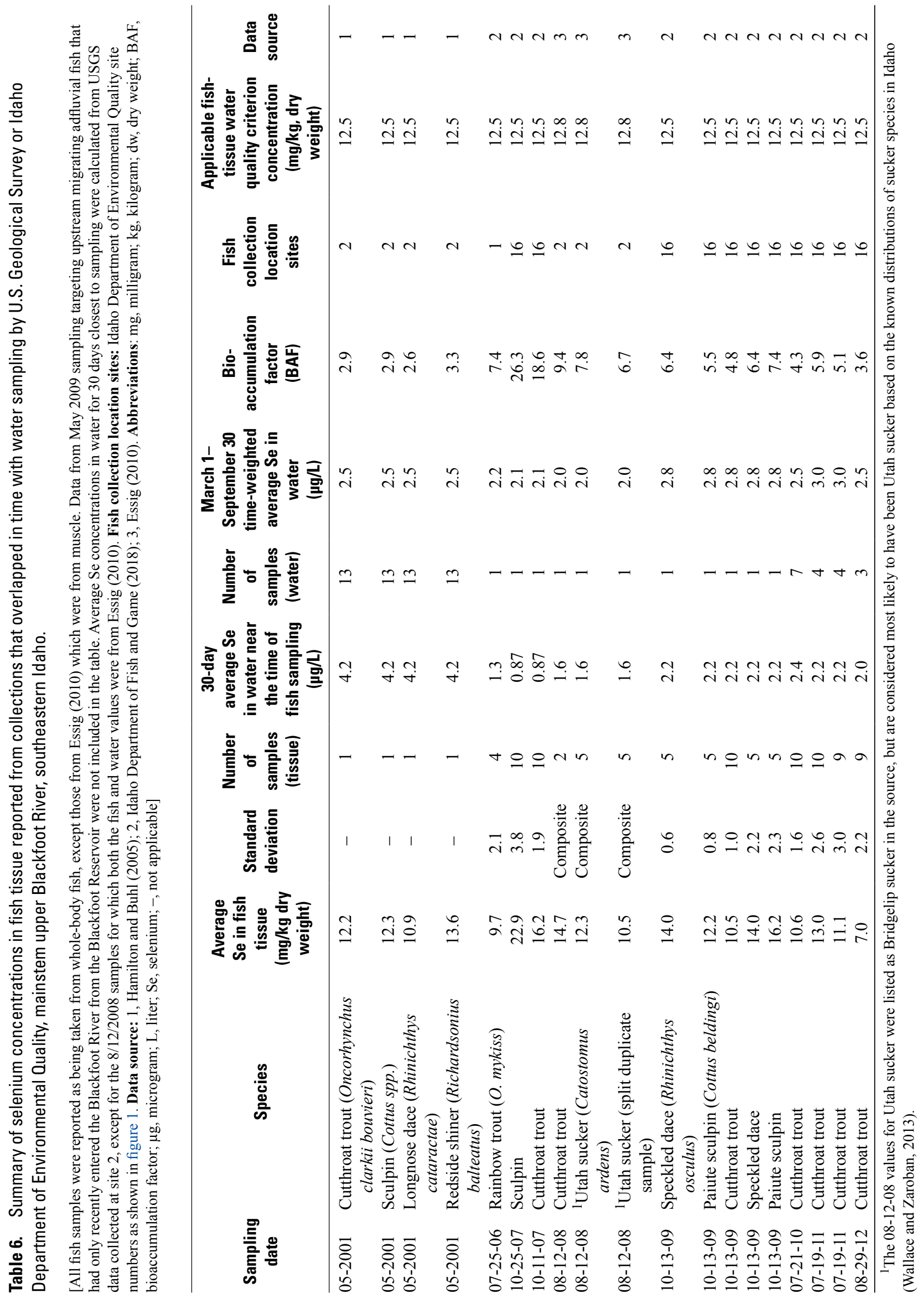


Except for the 2001 samples collected during May, all other fish samples listed in table 6 were collected during August to October baseflow conditions. Corresponding selenium concentrations in water during those times were relatively low, ranging from 0.9 to $2.4 \mu \mathrm{g} / \mathrm{L}$. Selenium samples in cutthroat trout, the species with the most data, ranged from 7 to $16 \mathrm{mg} / \mathrm{kg}$ dry weight, with no obvious relations between the selenium concentrations in fish compared to water. The highest concentrations of selenium in fish occurred at the same time as the lowest concentrations of selenium in water (October 2007), and the selenium content in fish collected in May 2001 was unremarkable even though this time had the highest water selenium concentrations of any sample groups. As a result of this disparity, BAFs varied by 10 times, from 2.6 to 26 (table 6).

The specifics of future monitoring strategies guided by the updated selenium criterion scheme will likely evolve, as some of the terms are undefined by the rule (Idaho Department of Environmental Quality, 2017) or in the national selenium criteria document (U.S. Environmental Protection Agency, 2016), where most terms originated. For instance, "elevated selenium concentrations" (U.S. Environmental Protection Agency, 2016, p. 737-780) is not further defined and does not distinguish whether "elevated" is intended to be relative to background concentrations or relative to criteria values. No definition is given for what is considered steady-state in "steady-state condition fish tissue data" (U.S. Environmental Protection Agency, 2016, p. 737-780). For example, selenium in water varies on seasonal, interannual, and possibly decadal time frames (figs. 3, 4, and 6), and presumably selenium concentrations in water influence selenium concentrations in fish tissue. The cutthroat trout data (table 6 ) varied by over two times between samplings, yet the 2001 and 2011 concentrations were nearly identical. The lowest cutthroat trout value was from 2012, which was one of the years with the lowest maximum 30-day average concentrations $(3.9 \mu \mathrm{g} / \mathrm{L})$ but also with the highest low-flow selenium concentrations and a middling time-weighted average concentration of 2.5 $\mu \mathrm{g} / \mathrm{L}$ from March 1 through September 30 (fig. 5, table 1).

These data suggest that for evaluating trends and the effectiveness of mitigation measures, systematic sampling of selenium in water should continue. Coordinated, systematic fish collections targeting the same species year to year, with samples collected near the water sampling site(s), would seem to be the best case for detecting potential trends and evaluating criterion compliance. Only fish tissue samples collected in 2001 and 2008 were collected from the same location as the water sampling. Although the available water data indicates selenium concentrations are similar among sample locations on the mainstem Blackfoot River (fig. 8), colocating fish and water sampling is one way to potentially reduce variability and strengthen the correlation between selenium in water and fish.

\section{Summary}

Increased baseflow concentrations of selenium from 2009 to 2013 and unaccounted streamflow and selenium loads in the Blackfoot River near Dry Valley indicate that alluvial groundwater may be a source of selenium loading to the Blackfoot River during runoff and baseflow conditions. However, an improved understanding of shallow alluvial aquifers throughout the upper Blackfoot River watershed would be useful for understanding the extent of selenium transport through this mechanism. The increasing trends in selenium observed from 2001 to 2012 during runoff and baseflow conditions (Mebane and others, 2015) were short-lived in the context of the longer water-quality record of 2001 to 2016. However, increased median runoff selenium concentrations from about 2005 through 2011 may illustrate an important aspect of selenium transport in the watershed. Namely, high snowmelt years provide a physical mechanism for transporting selenium through cross-valley dumps, and a geochemical mechanism for increased weathering of available selenium in these dumps. Additional weathering may thus manifest as higher selenium loads transported to streams during runoff and baseflow in following years. This finding suggests that thoughtful management of stormwater and snowmelt runoff on mining affected lands throughout the watershed may be important for limiting waste rock weathering and subsequent selenium release and transport throughout the watershed.

\section{Acknowledgments}

Primary funding for the U.S. Geological Survey (USGS) streamgaging and water-quality data collection at USGS station 13063000 was from the U.S. Department of Interior, Bureau of Land Management. The authors thank the Fish Sampling Protocol Technical Team for compiling and furnishing the data in table 6; data are available by contacting the Idaho Department of Fish and Game, Southeast Regional Office, Pocatello, Idaho. The authors would like to thank the USGS staff who have supported the streamflow measurements and water-quality data collection over the years, including Jay Bateman, Donald Coles, Robert Erickson, Mark Hardy, Nathan "Jake" Jacobson, James Johnson, Stan Landon, Robert Reaves, and Brad Vande Kamp. Funding for the seepage study and this analysis was from the Idaho Department of Environmental Quality (IDEQ) and USGS. The authors would like to thank the many people who have assisted in the IDEQ data collection, including Michelle Byrd, Kelsey Flandro, David Goings, Andrew Ray, Joshua Schultz, Melissa Thompson, Michael Rowe, Christine Waite (IDEQ); Victoria Burkhardt, Will Frymire, and Darrel Vanderweg (U.S. Forest Service); Sandi Fisher (U.S. Fish and Wildlife Service); Dean Fox (U.S. Bureau of Land Management); and Justin Skinner (Agrium, Inc.). Reviews of earlier versions of this report by Christian Schmidt (USGS Idaho Water Science Center, Boise, Idaho), Gregory Clark (USGS emeritus), and Alexandra Etheridge (USGS California Water Science Center) were greatly appreciated. 


\section{References Cited}

AECOM Technical Services, Inc., 2015a, North Maybe Mine East Mill Operable Unit, baseline monitoring samplesCaribou National Forest, Idaho: Sacramento, California, AECOM Technical Services, Inc., 2013 Data Summary Report, prepared for Nu-West Industries, Inc., Soda Springs, Idaho, $6815 \mathrm{p}$.

AECOM Technical Services, Inc., 2015b, North Maybe Mine East Mill Operable Unit, baseline monitoring samplesCaribou National Forest, Idaho: Sacramento, California, AECOM Technical Services, Inc., 2014 Data Summary Report, prepared for Nu-Qest Industries, Inc., Soda Springs, Idaho, 473 p.

Amacher, M.C., Brown, R.W., Sidle, R.C., and Kotuby-Amacher, J., 1995, Effect of mine waste on element speciation in headwater streams, in Allen, H.E., Huang, C.-P., Bailey, G.W., and Bowers, A.R., eds., Metal speciation and contamination of soil: Ann Arbor, Michigan, Lewis Publishers, p. 275-309.

Angradi, T.R., 1991, Transport of coarse particulate organic matter in an Idaho river, USA: Hydrobiologia, v. 211, no. 3, p. 171-183, 10.1007/BF00008533.

Arcadis U.S., Inc., 2016, Final 2015 data summary report, North Maybe Mine, Creeks Sub-Operable Unit, Caribou County, Idaho: Highlands Ranch, Colorado, Arcadis U.S., Inc., prepared for $\mathrm{Nu}$-West Industries, Inc./Nu-West Mining, Inc., $19477 \mathrm{p}$.

Bureau of Land Management, 2011, Final environmental impact statement—Blackfoot Bridge Mine: Pocatello Field Office, Bureau of Land Management, 874 p., accessed March 22, 2013 at http://www.monsanto.com/soda-springs/ Pages/blackfoot-bridge.aspx.

Bureau of Land Management and U.S. Forest Service, 2016, Final environmental impact statement - Volume 1, Rasmussen Valley Mine, Caribou County, Idaho: Pocatello Field Office, Caribou-Targhee National Forest, U.S. Department of the Interior, U.S. Department of Agriculture. 1183 p, accessed April 6, 2017, at https://eplanning.blm. gov/epl-front-office/eplanning/docset_view.do?projectId $=48$ 240\&currentPageId=62914\&documentId=80012.

Chapman, P.M., Adams, W.J., Brooks, M.L., Delos, C.G., Luoma, S.N., Maher, W.A., Ohlendorf, H.M., Presser, T.S., and Shaw, D.P., 2009, Ecological assessment of selenium in the aquatic environment: Summary of a SETAC Pellston Workshop, p. 339
Cleveland, W.S., Grosse, E., and Shyu, W.M., 1992, Local regression models, in Chambers, J.M., and Hastie, T., eds., Statistical models in S: Pacific Grove, California, Wadsworth \& Brooks/Cole Advanced Books \& Software, p. 309-376.

Cleveland, W.S., and Devlin, S.J., 1988, Locally weighted regression: an approach to regression analysis by local fitting: Journal of the American Statistical Association, v. 83 , no. 403 , p. 596-610, also available at http://dx.doi.org /10.1080/01621459.1988.10478639.

Conley, J.M., 2012, Evaluation of selenium in biotic and abiotic ecosystem components of the upper Blackfoot River Watershed: Raleigh, N.C., prepared for Greater Yellowstone Coalition, North Carolina State University, Department of Environmental and Molecular Toxicology, p. 36.

Eaton, A.D., Clesceri, L.S., Rice, E.W., and Greenberg, A.E., eds., 2005, Standard methods for the examination of water and wastewater: Washington D.C., American Public Health Association, American Water Works Association, and Water Environment Federation, variously paged.

Essig, D.A., 2010, Arsenic, mercury, and selenium in fish tissue and water from Idaho's major rivers: a statewide assessment, 118 p., accessed May 22, 2018, at https://www. deq.idaho.gov/media/639752-arsenic_mercury_fish_tissue_ report_0310.pdf.

Garbarino, J.R., 1999, Methods of analysis by the U.S. Geological Survey National Water Quality LaboratoryDetermination of dissolved arsenic, boron, lithium, selenium, strontium, thallium, and vanadium using inductively coupled plasma-mass spectrometry: U.S. Geological Survey Open-File Report 99-093, 31 p., https:// pubs.er.usgs.gov/publication/ofr9993.

Garbarino, J.R., Kanagy, L.K., and Cree, M.E., 2006, Determination of elements in natural-water, biota, sediment, and soil samples using collision/reaction cell inductively coupled plasma-mass spectrometry: U.S. Geological Survey Techniques and Methods, book 5, chap. B1, 88 p., https:// pubs.er.usgs.gov/publication/tm5B1.

Granato, G.E., 2009, Computer programs for obtaining and analyzing daily mean streamflow data from the U.S. Geological Survey National Water Information System Web Site: U.S. Geological Survey Open-File Report 2008-1362, 123 p. on CD-ROM, 5 appendixes, http://pubs.er.usgs.gov/ publication/ofr20081362. 
Grauch, R.I., Desborough, G.A., Meeker, G.P., Foster, A.L., Tysdal, R.G., Herring, J.R., Lowers, H.A., Ball, B.A., Zielinski, R.A., and Johnson, E.A., 2004, Petrogenesis and mineralogic residence of selected elements in the meade peak phosphatic shale member of the permian phosphoria formation, Southeast Idaho, chap. 8 of Hein, J.R., ed., Handbook of exploration and environmental geochemistry: Elsevier Science B.V., v. 8, p. 189-226, also available at http://www.sciencedirect.com/science/article/pii/ S187427340480010X.

Hamilton, S.J., 2004, Review of selenium toxicity in the aquatic food chain: The Science of the Total Environment, v. 326, no. 1-3, p. 1-31, also available at http://dx.doi. org/10.1016/j.scitotenv.2004.01.019.

Hamilton, S.J., and Buhl, K.J., 2005, Selenium in the Blackfoot, Salt, and Bear River Watersheds: Environmental Monitoring and Assessment, v. 104, no. 1, p. 309-339, 10.1007/s10661-005-1618-4.

Hamilton, S.J., Buhl, K.J., and Lamothe, P.J., 2004, Selenium and other trace elements in water, sediment, aquatic plants, aquatic invertebrates, and fish from streams in SE Idaho near phosphate mining, chap. 18 of Hein, J.R., ed., Handbook of exploration and environmental geochemistry: Elsevier Science B.V., v. 8, p. 483-525, also available at http:/www.sciencedirect.com/science/article/pii/ S1874273404800202.

Hay, M.B., Leone, G., Partey, F., and Wilking, B., 2016, Selenium attenuation via reductive precipitation in unsaturated waste rock as a control on groundwater impacts in the Idaho phosphate patch: Applied Geochemistry, v. 74, p. 176-193, also available at http://dx.doi.org/10.1016/j. apgeochem.2016.09.008.

Hein, J.R., ed., 2004, Life cycle of the phosphoria formationFrom deposition to the post-mining environment, in Handbook of exploration and environmental geochemistry: Elsevier Science B.V., v. 8, 635 p.

Herring, J.R., 2004, Rock leachate geochemistry of the meade peak phosphatic shale member of the phosphoria formation, Southeast Idaho, chap. 13 of Hein, J.R., ed., Handbook of exploration and environmental geochemistry: Elsevier Science B.V., v. 8, p. 367-397, also available at http://www. sciencedirect.com/science/article/pii/S1874273404800159.

Herring, J.R., and Grauch, R.I., 2004, Lithogeochemistry of the meade peak phosphatic shale member of the phosphoria formation, Southeast Idaho, chap. 12 of Hein, J.R., ed., Handbook of exploration and environmental geochemistry: Elsevier Science B.V., p. 321-366, also available at http://www.sciencedirect.com/science/article/pii/ S1874273404800147.
Hirsch, R.M., 1982, A comparison of four streamflow record extension techniques: Water Resources Research, v. 18 , no. 4, p. 1081-1088, also available at http://dx.doi. org/10.1029/WR018i004p01081.

Idaho Department of Environmental Quality, variously dated, IDAPA 58.01.02 - Water quality standards, title 1, chapter 2: Pocatello, Idaho, Idaho Department of Environmental Quality, 180 p., accessed May 22, 2018, at https:// adminrules.idaho.gov/rules/current/58/0102.pdf.

Idaho Department of Environmental Quality, 2017, IDAPA 58.01.02 - Water quality standards, title 1, chapter 2 , docket no. 58-0102-1701, Notice of rulemaking-Proposed rulemaking: Pocatello, Idaho, Idaho Department of Environmental, 21 p., accessed May 22, 2018, at http:// www.deq.idaho.gov/media/60180627/58-0102-1701proposed-rule-notice-0817.pdf.

Idaho Department of Fish and Game, 2018, Master database of fish tissue selenium concentrations collected in waterbodies in southeast Idaho: Pocatello, Idaho Department of Fish and Game database, Southeast Regional Office.

Knudsen, A.C., and Gunter, M.E., 2004, The effects of weathering on the mineralogy of the phosphoria formation, Southeast Idaho, chap. 7 of Hein, J.R., ed., Handbook of exploration and environmental geochemistry: Elsevier Science B.V., v. 8, p. 169-187, also available at http:/www. sciencedirect.com/science/article/pii/S1874273404800093.

Maher, W.A., Roach, A., Doblin, M.A., Fan, T.W.-M., Foster, S., Garrett, R., Moller, G., Oram, L.L., and Wallschlager, D., 2010, Environmental sources, speciation, and partitioning of selenium, in Chapman, P.M., Adams, W.J., Brooks, M.L., Delos, C.G., Luoma, S.N., Maher, W.A., Ohlendorf, H.M., Presser, T.S., and Shaw, D.P., eds., Ecological assessment of selenium in the aquatic environment: Pensacola, Florida, SETAC Press, p. 47-92.

Mars, J.C., and Crowley, J.K., 2003, Mapping mine wastes and analyzing areas affected by selenium-rich water runoff in southeast Idaho using AVIRIS imagery and digital elevation data: Remote Sensing of Environment, v. 84, no. 3, p. 422-436, also available at http://dx.doi. org/10.1016/S0034-4257(02)00132-3.

McNeal, J.M., and Balistrieri, L.S., 1989, Geochemistry and occurrence of selenium-An overview, in Jacobs, L.W., ed., Selenium in agriculture and the environment-SSSA special publication: Madison, WI, Soil Science Society of America and American Society of Agronomy, p. 1-13., 10.2136/ sssaspecpub23.c1. 
Mebane, C.A., Mladenka, G., Van Every, L., Williams, M.L., Hardy, M.A., and Garbarino, J.R., 2015, Selenium in the upper Blackfoot River watershed, southeastern Idaho, 2001-12: U.S. Geological Survey Scientific Investigations Report 2014-5203 (ver. 1.1), 34 p, plus appendixes, http:// dx.doi.org/10.3133/sir20145203.

Mladenka, G., Van Every, L., Zinsser, L.M., and Mebane, C.A., 2018, Selenium in the upper Blackfoot River watershed, Idaho, 2001-2016: Digital datasets, http://dx.doi. org $/ 10.6084 / \mathrm{m} 9$.figshare.5405662.

Moyle, P.R., and Kayser, H.Z., 2006, Spatial database of mining-related features in 2001 at selected phosphate mines, Bannock, Bear Lake, Bingham, and Caribou Counties, Idaho: U.S. Geological Survey Data Series 223, 58 p., 1 pl., also available at http://pubs.er.usgs.gov/publication/ds223.

Mueller, D.K., Schertz, T.L., Martin, J.D., and Sandstrom, M.W., 2015, Design, analysis, and interpretation of field quality-control data for water-sampling projects: U.S. Geological Survey Techniques and Methods, book 4, chap. C4, 54 p., https://dx.doi.org/10.3133/tm4C4.

Natural Resources Conservation Service, 2017a, Slug Creek Divide Snotel (761): U.S. Department of Agriculture database, accessed June 2017 at https://wcc.sc.egov.usda. gov/nwcc/site?sitenum $=761$.

Natural Resources Conservation Service, 2017b, Somsen Ranch Snotel (770): U.S Department of Agriculture, accessed January 12, 2017, at https://wcc.sc.egov.usda.gov/ nwcc/site? sitenum $=770$.

Nordstrom, D.K., 2009, Acid rock drainage and climate change: Journal of Geochemical Exploration, v. 100, no. 2, p. 97-104, also available at https://doi.org/10.1016/j. gexplo.2008.08.002.

Oberg, K.A., Morlock, S.E., and Caldwell, W.S., 2005, Quality-assurance plan for discharge measurements using acoustic Doppler current profilers: U.S. Geological Survey Scientific Investigations Report 2005-5183, 41 p, also available at http://pubs.er.usgs.gov/publication/sir20055183.

Oram, L.L., Strawn, D.G., Marcus, M.A., Fakra, S.C., and Möller, G., 2008, Macro- and microscale investigation of selenium speciation in Blackfoot River, Idaho sediments: Environmental Science \& Technology, v. 42, no. 18, p., 6830-6836, 10.1021/es7032229.

Oram, L.L., Strawn, D.G., Morra, M.J., and Möller, G., 2010, Selenium biogeochemical cycling and fluxes in the hyporheic zone of a mining-impacted stream: Environmental Science \& Technology, v. 44, no. 11, p. 4176-4183, 10.1021/es100149u.
Paul, A.P., Garbarino, J.R., Olsen, L.D., Rosen, M.R., Mebane, C.A., and Struzeski, T.M., 2016, Potential sources of analytical bias and error in selected trace element dataquality analyses: Reston, Virginia, 2016-5135, 68 p, also available at http://pubs.er.usgs.gov/publication/sir20165135.

Perkins, R.B., and Foster, A.L., 2004, Mineral affinities and distribution of selenium and other trace elements in black shale and phosphorite of the phosphoria formation, chap. 10 of Hein, J.R., ed., Handbook of exploration and environmental geochemistry: Elsevier Science B.V., p. 251-295, also available at http://www.sciencedirect.com/ science/article/pii/S1874273404800123.

Presser, T.S., Hardy, M., Huebner, M.A., and Lamothe, P.J., 2004a, Selenium loading through the Blackfoot River watershed-Linking sources to ecosystems, chap. 16 of Hein, J.R., ed., Handbook of exploration and environmental geochemistry: Elsevier Science B.V., p. 437-466, also available at $\mathrm{http}: / / \mathrm{www}$. sciencedirect.com/science/article/ pii/S1874273404800184.

Presser, T.S., and Luoma, S.N., 2010, A methodology for ecosystem-scale modeling of selenium: Integrated Environmental Assessment and Management, v. 6, no. 4, p. 685-710, 10.1002/ieam.101.

Presser, T.S., Piper, D.Z., Bird, K.J., Skorupa, J.P., Hamilton, S.J., Detwiler, S.J., and Huebner, M.A., 2004b, The phosphoria formation-A model for forecasting global selenium sources to the environment, chap. 11 of Hein, J.R., ed., Handbook of exploration and environmental geochemistry: Elsevier Science B.V., p. 299-319, also available at http://www.sciencedirect.com/science/article/ pii/S1874273404800135.

Ralston, D.R., and Williams, R.E., 1979, Groundwater flow systems in the western phosphate field in Idaho: Journal of Hydrology (Amsterdam), v. 43, no. 1, p. 239-264, also available at http://dx.doi.org/10.1016/00221694(79)90175-6.

Riggs, H.C., 1972, Low-flow investigations: U.S. Geological Survey Techniques of Water-Resources Investigations, book 4, chap. B1, 18 p., also available at http://pubs.er.usgs.gov/ publication/twri04B1.

Sauer, V.B., and Turnipseed, D.P., 2010, Stage measurement at gaging stations: U.S. Geological Survey Techniques and. Methods book 3, chap. A7, 45 p., also available at https:// pubs.er.usgs.gov/publication/tm3A7.

Sidle, R.C., Farmer, E.E., and Williams, B.D., 1994, Subsidence and rock creep in a cross-valley fill: Environmental Geology, v. 24, no. 3, p. 159-165, also available at http://dx.doi.org/10.1007/bf00766885. 
Simonds, F.W., and Sinclair, K.A., 2002, Surface water-ground water interactions along the lower Dungeness River and vertical hydraulic conductivity of streambed sediments, Clallam County, Washington, September 1999-July 2001: U.S. Geological Survey Water-Resources Investigations Report 02-4161, 60 p., also available at http://pubs.er.usgs. gov/publication/wri024161.

Stillings, L.L., and Amacher, M.C., 2010, Kinetics of selenium release in mine waste from the Meade Peak Phosphatic Shale, Phosphoria Formation, Wooley Valley, Idaho: Chemical Geology, v. 269, no. 1-2, p. 113-123, also available at http://dx.doi.org/10.1016/j. chemgeo.2009.10.011.

U.S. Environmental Protection Agency, 1998, Method 6020A Inductively couple plasma-Mass spectrometry: Washington, D.C., U.S. Environmental Protection Agency, 23 p., also available at https://www.epa.gov/sites/ production/files/2015-07/documents/epa-6020a.pdf.

U.S. Environmental Protection Agency, 2016, Appendix KTranslation of a selenium fish tissue criterion element to a site-specific water column value: Washington, D.C., U.S. Environmental Protection Agency, p. 737-780 (K1-K44), also available at https://www.epa.gov/wqc/aquatic-lifecriterion-selenium.
U.S. Geological Survey, 2017a, Methods for quantifying streamflow measurement uncertainty for measurements stored in the National Water Information System: Reston, Virginia, U.S. Geological Survey, Office of Surface Water Technical Memo 2017.12, 3 p., also available at https:// water.usgs.gov/admin/memo/SW/sw17.12.pdf.

U.S. Geological Survey, 2017b, National Water Information System (NWIS): U.S. Geological Survey National Water Information System, accessed May 22, 2018, at https://nwis. waterdata.usgs.gov/nwis.

U.S. Geological Survey, variously dated, National field manual for the collection of water-quality data, U.S. Geological Survey Techniques of Water-Resources Investigations, book 9, chaps. A1-A10, accessed May 22, 2018, at http:// pubs.water.usgs.gov/twri9A.

Wallace, R.L., and Zaroban, D.W., 2013, Native fishes of Idaho: Bethesda, Maryland, American Fisheries Society, $216 \mathrm{p}$.

Wheeler, J.D., and Eddy-Miller, C.A., 2005, Seepage investigation on selected reaches of Fish Creek, Teton County, Wyoming, 2004: U.S. Geological Survey Scientific Investigations Report 2005-5133, 22 p., accessed May 22, 2018, at http://pubs.er.usgs.gov/publication/sir20055133.

Whetstone Associates, 2017, North Dry Valley Mine surface water and groundwater monitoring results, year 2016: Gunnison, Colorado, Whetstone Associates, 87 p. 


\section{Appendix 1. Data Quality Evaluations}

No selenium was detected in any of the 15 ambient or equipment blank samples analyzed during 2013-16, with laboratory reporting limits of 0.03 to 0.05 micrograms per liter $(\mu \mathrm{g} / \mathrm{L})$.

Variability in concurrent replicate samples collected by the autosampler, grab samples from a single point in the stream channel, or equal-width increment (EWI) samples was evaluated by comparing the relative sample deviation (RSD), also known as the coefficient of variability, and is defined as the standard deviation of all replicates values, divided by the average, expressed as a percentage. With selenium, 12 matched sets of automatically collected, grab, and EWI samples were evaluated (table 1.1). Of these, the median RSD was 2.8 percent, ranging from 0 to 6.9 percent.

For the majority of the selenium samples, the similar results between grab samples and automatically collected samples indicate that the sampler pumping system did not significantly affect samples. Likewise, the similarity between samples shows that the autosampler represented well the dissolved selenium in the stream cross section. By implication, in this well-mixed location distant from any seeps or selenium sources, EWI samples add little information over grab or automatic samples, other than providing reassurance of the representativeness of the grab and autosamples.

\section{Comparisons of Laboratory Results With External Quality Control Samples}

The preceding examination of quality control blank samples and the combined variability from environmental variability, different sampling methods, and inherent variability of laboratory analyses showed the absence of measurable cross contamination of samples from field or laboratory processing and analyses, and showed high precision in the reported selenium concentrations. However, precision and accuracy are two different concepts and neither the absence of contamination nor high precision demonstrate the accuracy of the laboratory analyses. Underlying the variability in the comparisons among the field sampling methods is the intrinsic measurement uncertainty of the laboratory analyses. A previous evaluation of selenium trends in the upper Blackfoot River watershed suggested a slight but persistent and increasing low bias to the laboratory results (Mebane and others, 2015). Other external evaluations showed that although the U.S. Geological Survey (USGS) National Water Quality Laboratory (NWQL) selenium analyses generally met established data quality objectives (generally \pm 20 percent of quality control sample values, in addition to internal control limits), selenium analyses had a slight but systematic low bias (Paul and others, 2016). Although the NWQL maintains a strict regimen of internal controls and external validation in keeping with industry good laboratory practices (http:// wwwnwql.cr.usgs.gov/USGS_Quality.shtml), in this study we are seeking to detect subtle trends over time, which depends upon accurate and precise laboratory performance. Thus, we examined the potential for analytical bias to affect our interpretations, and we also evaluated external quality testing of the NWQL in some detail.

First, we considered the measurement uncertainty of the laboratory analyses by evaluating the accuracy and bias of selenium results obtained for blind, standard reference samples. During the period of our study, 2013-16, the USGS NWQL analyzed 359 blind standard reference samples (filtered river water samples that had been spiked with selenium and other inorganics) through the USGS Bureau of Quality Services Inorganic Blind Sample Program. These results were matched with the most probable values (MPVs) obtained from round robin sampling (fig. 1.1). The round robin MPVs are assumed here to represent "true" concentrations, although MPVs have their own variability and uncertainties. The agreement between MPVs and measured values can be examined quantitatively by calculating the percent recovery of the laboratory samples which reflects the inherent measurement uncertainty and any tendencies toward a positive or negative bias in the data (fig. 1.2). The percent recoveries were evaluated for bias trends over time through locally weighted (LOESS) regression Cleveland and Devlin, 1988). The absence of bias would be indicated by even distribution of percent recovery values above and below the 100 percent recovery line. Visually, the percent recoveries show a distinct negative bias that seemed to strengthen from 2014 to 2016 (fig. 1.1). A closer inspection of absolute values behind the relative percent recoveries suggests a concentration dependence to the bias, and that the great majority of the standard reference samples analyzed by the NWQL through the Inorganic Blind Sample Program were low, with 80 percent of the MPVs less than $0.8 \mu \mathrm{g} / \mathrm{L}$ and with a median MPV of $0.58 \mu \mathrm{g} / \mathrm{L}$ (fig. 1.1 and underlying data). These concentrations are lower than the vast majority of concentrations measured in the upper Blackfoot River watershed study, for which 90 percent of the samples were greater than $1.2 \mu \mathrm{g} / \mathrm{L}$. The grand average from 2010 to 2016 was $3.5 \mu \mathrm{g} / \mathrm{L}$, ranging from 0.5 to $13.8 \mu \mathrm{g} / \mathrm{L}, \mathrm{n}=619$. 


\section{Spatial and Temporal Trends in Selenium in the Upper Blackfoot River Watershed, Idaho, 2001-16}

Two additional lines of evidence are relevant to the question of whether the low bias apparent from the Inorganic Blind Sample Program samples at low concentrations (figs. 1.1 and 1.2) held at the higher concentrations that were more representative of concentrations encountered in the upper Blackfoot River watershed study area. First, split samples from the Blackfoot River and tributaries were analyzed by the NWQL and SVL Analytical (SVL; Kellogg, Idaho). SVL has provided chemical analyses for Blackfoot River monitoring by IDEQ since 2008 (Mladenka and others, 2018). As this report relied on data from the IDEQ and USGS sampling, SVL provided blind standard reference samples for analysis, and six pairs of split samples were analyzed by the NWQL and SVL. The results (table 1.2) show close agreement between the SVL results and the USGS standard reference samples, and close agreement between the NWQL and SVL sample pairs.

In the second approach to evaluate the NWQL results for bias in the concentration range of most concern in the present study (about 1 to $10 \mu \mathrm{g} / \mathrm{L}$ ), selenium interlaboratory quality comparison testing comparisons were evaluated. The NWQL participates in the semiannual standard reference sample round robin tests with one concentration per cycle (https://bqs.usgs. gov/srs/), and in annual performance testing by Environment
Canada (which provides accredited proficiency tests for laboratories) with 10 concentrations per cycle (https://nwql. usgs.gov/Public/perf_eval.shtml). The results obtained with these reference samples during 2013-16 are plotted against the expected most probable values for the samples, with arbitrarily selected performance bounds of \pm 20 percent (fig. 1.3). Only for the lowest concentration in the dataset was the NWQL measurement well outside of the \pm 20 percent performance bounds. A high bias is discernable at about greater than 30 $\mu \mathrm{g} / \mathrm{L}$ selenium. However, figure 1.3 shows at least that at selenium concentrations greater than about $0.5 \mu \mathrm{g} / \mathrm{L}$, selenium results provided by the NWQL were highly repeatable and acceptably precise and accurate. Together, the various data quality evaluations indicate that the combined field and laboratory processes give highly repeatable results, and for the conditions encountered in the upper Blackfoot River watershed study, reported concentrations were sufficiently precise and sufficiently accurate. During 2013-16, NWQL reported selenium concentrations of about less than or equal to $0.5 \mu \mathrm{g} / \mathrm{L}$ were likely low biased; however, few concentrations nearly this low were reported among the upper Blackfoot River watershed dataset during this period. 
Table 1.1. Matched quality control sample results collected from replicate automated pump sampler, grab samples, and equal width increment samples.

[Abbreviations: auto, automated pump sampler; EWI, equal width increment; RSD, relative sample deviation; $\mu \mathrm{g} / \mathrm{L}$, micrograms per liter]

\begin{tabular}{|c|c|c|c|}
\hline Date & $\begin{array}{c}\text { Sample } \\
\text { type }\end{array}$ & $\begin{array}{c}\text { Dissolved selenium } \\
(\mu \mathrm{g} / \mathrm{L})\end{array}$ & $\begin{array}{c}\text { Relative sample deviation } \\
\text { (percent) }\end{array}$ \\
\hline May 2, 2013 & Auto & 3.4 & 1.7 \\
\hline May 2, 2013 & Grab & 3.5 & \\
\hline May 2, 2013 & EWI & 3.4 & \\
\hline June 25, 2013 & Auto & 2.4 & 0.0 \\
\hline June 25, 2013 & Grab & 2.4 & \\
\hline June 25,2013 & EWI & 2.4 & \\
\hline September 16, 2013 & Auto & 1.7 & 2.8 \\
\hline September 16, 2013 & Grab & 1.8 & \\
\hline September 16, 2013 & Grab & 1.8 & \\
\hline September 16, 2013 & EWI & 1.8 & \\
\hline May 13, 2014 & EWI & 5.5 & 6.3 \\
\hline May 13, 2014 & Grab & 4.9 & \\
\hline May 13, 2014 & Auto & 5 & \\
\hline July 10, 2014 & Auto & 1.4 & 0.0 \\
\hline July 10, 2014 & Grab & 1.4 & \\
\hline September 16, 2014 & Auto & 1.5 & 3.7 \\
\hline September 16, 2014 & EWI & 1.6 & \\
\hline September 16, 2014 & Grab & 1.6 & \\
\hline May 6, 2015 & Auto & 4.6 & 3.1 \\
\hline May 6, 2015 & EWI & 4.4 & \\
\hline July 13,2015 & Auto & 1.1 & 0.0 \\
\hline July 13, 2015 & Auto & 1.1 & \\
\hline July 13,2015 & Grab & 1.1 & \\
\hline September 24, 2015 & Auto & 0.97 & 6.9 \\
\hline September 24, 2015 & Grab & 0.99 & \\
\hline September 24, 2015 & EWI & 1.1 & \\
\hline April 21, 2016 & Auto & 3.8 & 3.6 \\
\hline April 21, 2016 & Grab & 4 & \\
\hline July 13, 2016 & Grab & 1.5 & 0.0 \\
\hline July 13, 2016 & Auto & 1.5 & \\
\hline September 21, 2016 & Grab & 1.6 & 3.7 \\
\hline September 21, 2016 & EWI & 1.6 & \\
\hline September 21, 2016 & Auto & 1.5 & \\
\hline Maximum RSD & & & 6.9 \\
\hline 90 percentile RSD & & & 5.7 \\
\hline Median RSD & & & 2.8 \\
\hline$n$ comparisons & & & 12 \\
\hline
\end{tabular}


Table 1.2. Interlaboratory comparison of selenium samples, Blackfoot River, Idaho, June 2016.

[RPD: Relative percent difference. Abbreviations: NWQL, National Water Quality Laboratory; Se, selenium; SRS, standard reference sample; SVL, SVL Analytical; USGS, U.S. Geological Survey; $\mu \mathrm{g} / \mathrm{L}$, microgram per liter]

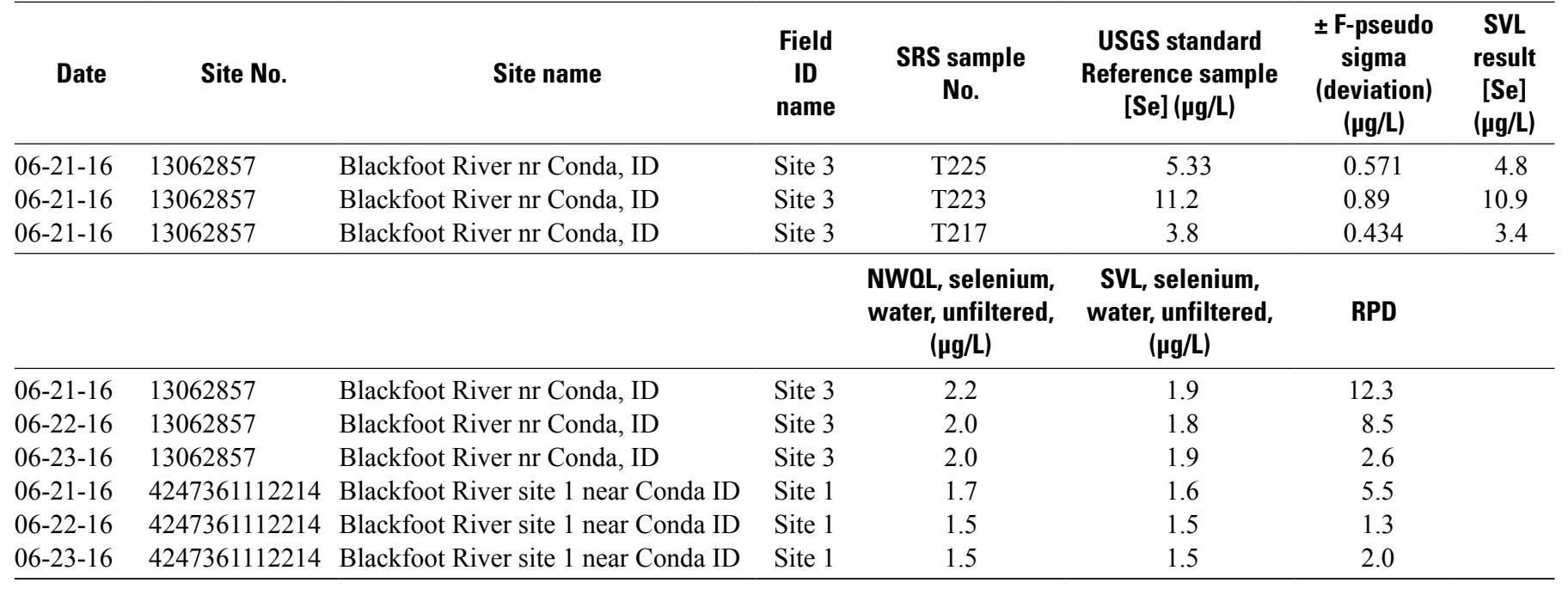

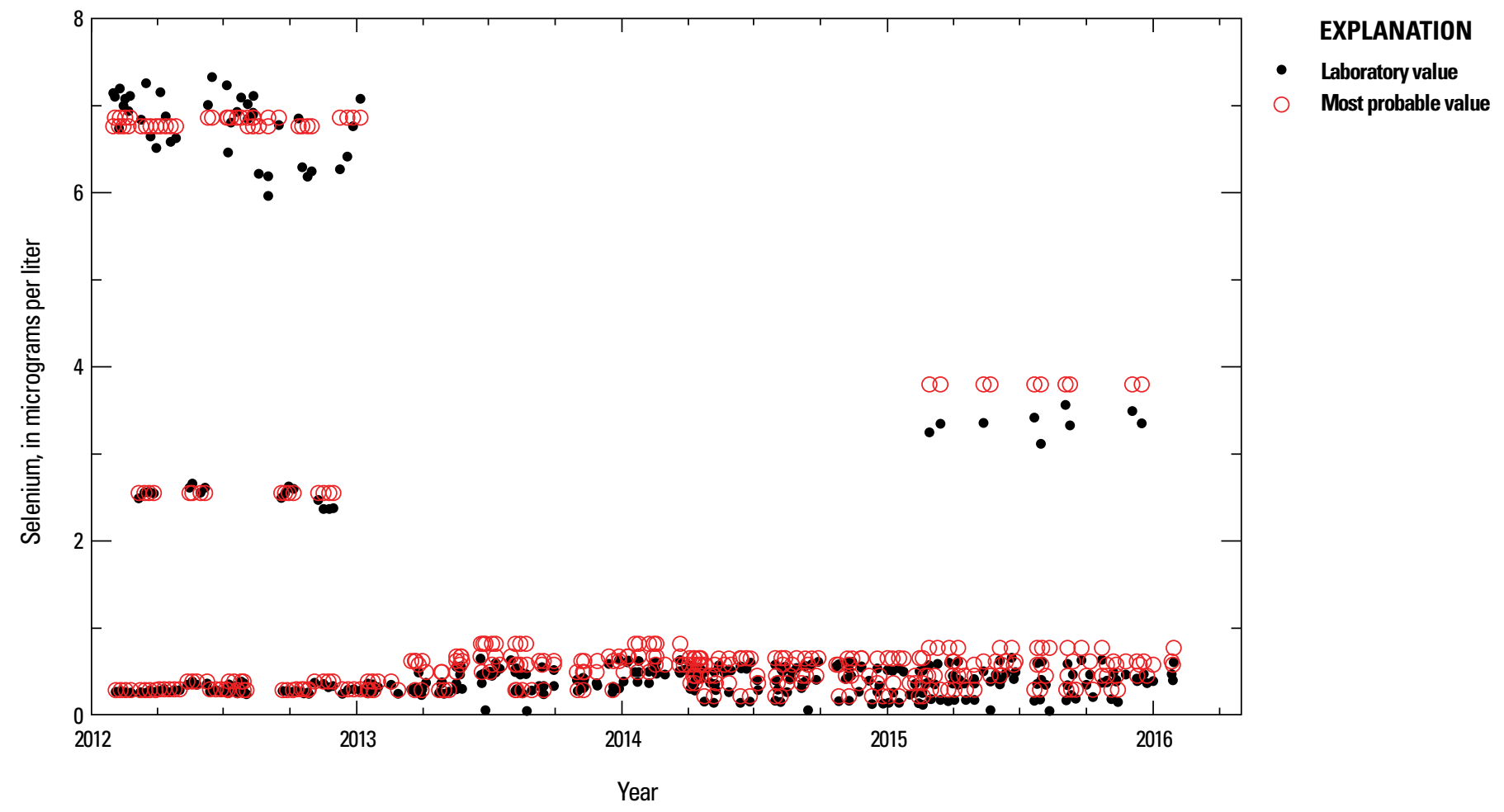

Figure 1.1. Quality control results of filtered selenium values measured by the U.S. Geological Survey National Water Quality Laboratory compared with the most probable values from round-robin testing of spiked filtered river water samples. 


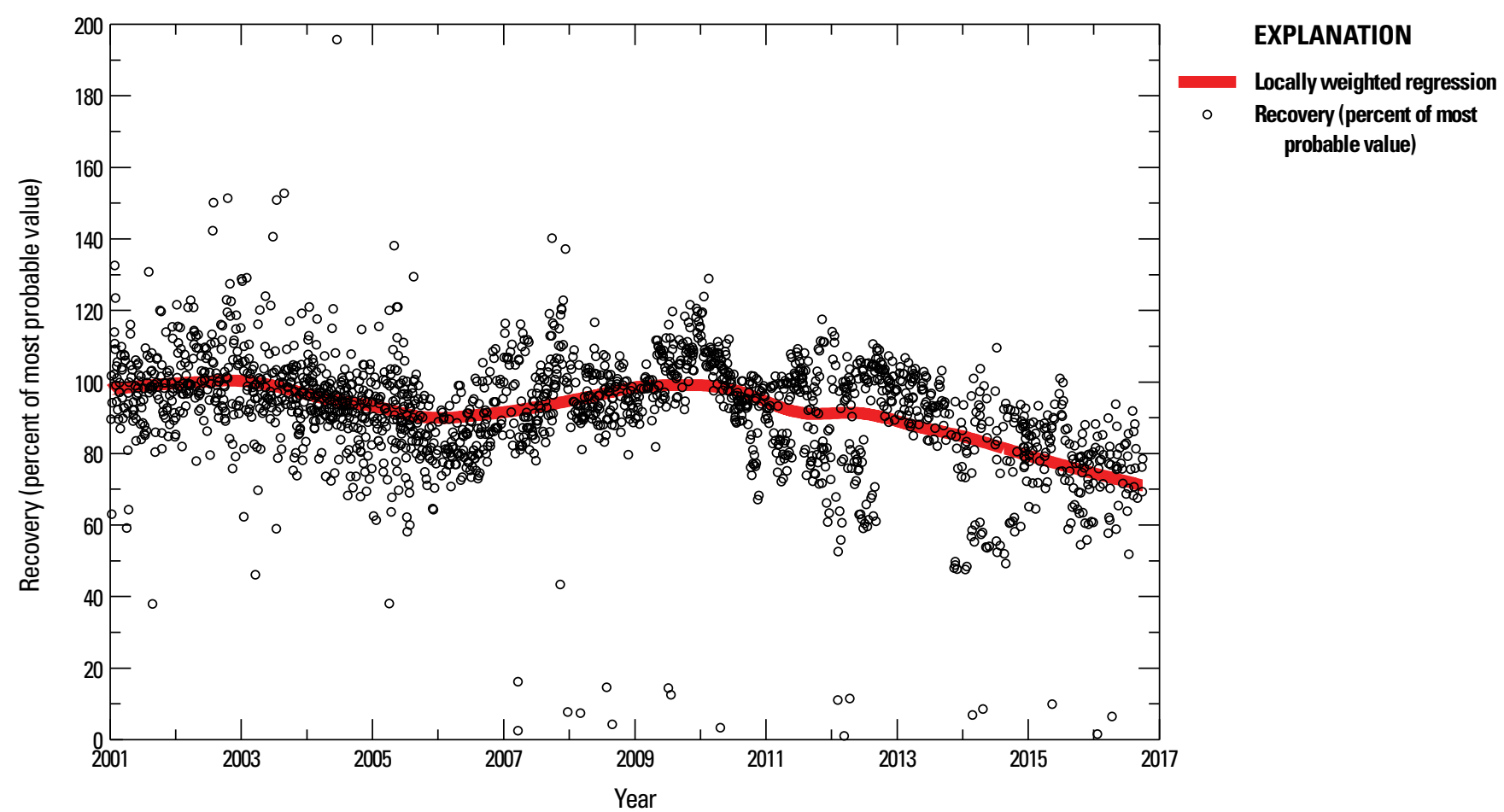

Figure 1.2. Accuracy and bias of selenium measurements made by the U.S. Geological Survey National Water Quality Laboratory with blind standard reference samples (spiked river water samples), as percentages of most probable values.

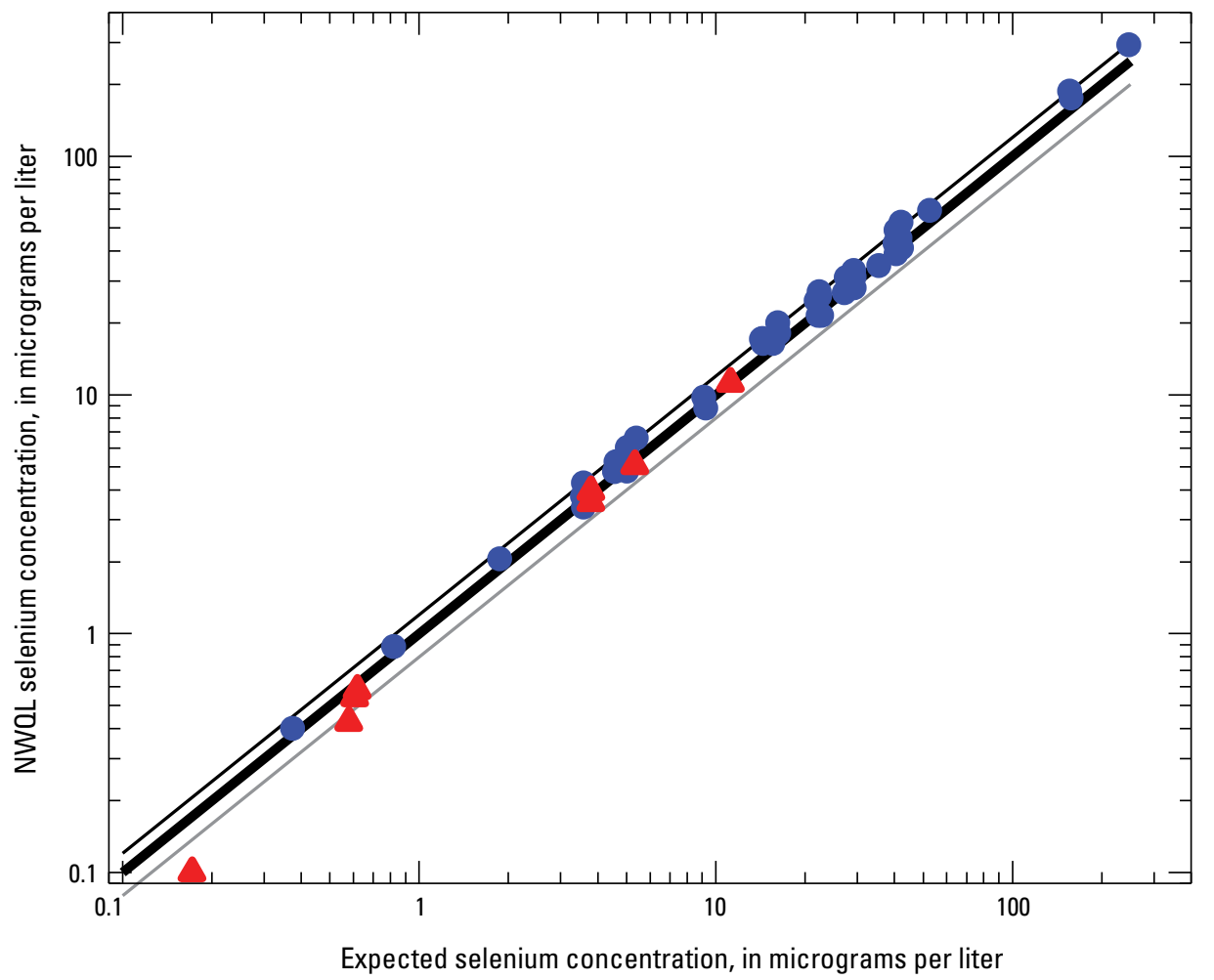

EXPLANATION

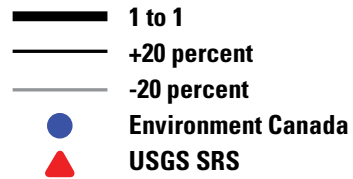

Figure 1.3. Selenium concentrations measured by the National Water Quality Laboratory compared to expected concentrations in round robin interlaboratory performance testing evaluations by Environment Canada or the U.S. Geological Survey Bureau of Quality Systems Standard Reference Sample programs. Except for the lowest selenium concentration that was clearly out of bounds, most samples were within \pm 20 percent bounds of the expected values. (Se, selenium; SRS, standard reference sample; $\mu \mathrm{g} / \mathrm{L}$, microgram per liter). 

Publishing support provided by the U.S. Geological Survey Science Publishing Network, Tacoma Publishing Service Center

For more information concerning the research in this report, contact the Director, Idaho Water Science Center

U.S. Geological Survey

230 Collins Road

Boise, Idaho 83702

https://www.usgs.gov/centers/id-water 
क्ञात 